\title{
PART ONE: DEBUNKING PREVAILING SCHOLARLY VIEWS PERTAINING TO THE APOSTASY OF ALLEGED DESCENDANTS OF SHAYKH YUSUF OF MAKASSAR ${ }^{1}$
}

\author{
Najma Moosa \\ University of the Western Cape, Republic of South Africa \\ email:nmoosa@uwc.ac.za
}

\begin{abstract}
This article focuses on the controversial issue of apostasy pertaining to the alleged family of Shaykh Yusuf of Makassar, the Indonesian pioneer of Islam in colonial South Africa, after his demise at the Cape in the late 17th century during a period of Dutch occupation of both countries. It is reported in local and international historical and scholarly sources that the second generation grandchildren of this political exile and learned Islamic scholar converted

1 The article forms part of a larger research project for which ethical clearance was obtained from the University of the Western Cape (UWC). Personal communications are used with permission. I acknowledge, with thanks, Professors S Dangor (Emeritus, UKZN) and E Nurlaelawati (UIN Sunan Kalijaga, Indonesia), Moulana T Karaan, Shaykh S Hendricks, Mr E Rhoda, Mr E Salie, Mr D Malan, Dr A Kok and the transnationally extended 'Shaykh Yusuf Big Family' and members of the Shaykh Yusuf Foundation IKSYAM (Ikatan Keluarga Besar Shaykh Yusuf Al Macassary), for their insightful contributions and for clarifiying, verifying and providing additional information and inspiration; Professors F du Toit and Jaap de Visser for their assistance with translations of Company records from Dutch into English, and I Leeman for his editorial assistance; Staff at UWC, especially the Law Librarian, Ms G Van Niekerk, and at UCT, Ms A Brey and Ms B Southgate, for their assistance in locating and securing copies of early publications; Archivist of the Dutch Reformed Church in South Africa, Ms C De Wet, for her kind assistance with locating a baptismal record. Given that history is not my area of expertise, all imaginative speculations of what could have occurred, including some controversial opinions and hypotheses, remain my own.
\end{abstract}


from Islam to Christianity at the Cape and thereafter entered into marriages with Christian spouses. Their mother is alleged to have been the Shaykh's daughter, Zytie Sara Marouff (alias Care Sale), and their father, the Rajah or King of Tambora (alias Abulbasi Sultan), a fellow exiled countryman. The marriage between the Rajah and Zytie is alleged to have taken place shortly after his arrival at the Cape in 1698 but before the death of Shaykh Yusuf in 1699. The conversions are recorded to have taken place within two decades of the Shaykh's death and shortly after the death of theirfather, the Rajah, in 1719; both averted death sentences but died during exile at the Cape. The main aim of this article is to critically analyse these sources, which contain both conflicting information, and whose authors express ambivalent views, in an attempt to unravel the mystery surrounding their conversion and the marriage of their parents. Although some local Muslim religious authorities (ulama) at the Cape are aware of these conversions, many are not. In fact, these conversions were overlooked in a publication on the very topic. Local Muslims have therefore not been fully apprised by them of this aspect of their bistory because the topic is understandably also a sensitive one. The aim of this article is therefore not to dispute these facts or even that these conversions may have been a voluntary exercise and a consequence of freedom of choice. Although an analysis of some of the policies of the then Dutch colonial government which were enforced at the Cape (for example, those pertaining to interracial and interreligious marriages amidst limited religious freedom) are referred to, this article highlights that socio-economic reasons (poverty) and practical expediency (marriage) may indeed have precipitated such conversions. A detailed critical analysis, including of the Islamic law (Shari'a) pertaining to freedom of religion and apostasy, is unfortunately beyond the scope of this article due to space constraints.

[Artikel ini membahas kontroversi pindah agama pada keluarga Syekh Yusus Makassar selepas diasingkan di Afrika Selatan pada masa kolonial Belanda akbir abad 17. Menurut sumber lokal dan tulisan sarjana internasional menyatakan babwa generasi kedua keturunan Syekh Yusuf telah memeluk. Kristen serta menikah dengan pasangan Kristen. Cucu yang dimaksud adalah anak dari putri Syekh Yusuf, Zytie Sara Marouff, yang menikah dengan Raja Tambora yang juga ikut dalam pengasingan di Cape Town. Pernikahan itu diperkirakan terjadi setelah rombongan tiba di Cape Town tahun 1698 dan sebelum wafatnya Syekh Yusuf tahun 1699. 
Sedangkan konversi agama yang terjadi sekitar dua dekade setelah wafatnya Syekh Yusuf dan selepas wafat ayah mereka Raja Tambora tahun 1719. Fokus utama artikel ini adalah mengkritisi sumber-sumber informasi yang bertentangan dan pandangan-pandangan para penulis yang ambivalen dalam rangka memperjelas misteri mengenai konversi dan pernikahan kedua orang tua mereka. Walaupun ulama lokal di Cape Town menyadari tentang konversi tersebut, namun sebagian besar tidak memperdulikannya. Sayangnya konversi ini dilibat berlebiban dalam berbagai tulisan. Lagipula penduduk. muslim setempat tidak menjelaskan informasi hal ini pada catatan sejarah mereka karena dipabami sebagai hal yang sensitif. Oleh karena itu, artikel ini tidak bermaksud untuk. memperdebatkan atau babkan menguji fakta mengenai konversi agama yang memang bagian dari hak kebebasan beragama. Walaupun artikel membahas pelaksanaan kebijakan kolonial Belanda (misal pembatasan pernikahan antar ras dan antar agama ditengah pembatasan kebebasan beragama), artikel ini juga membahas sekilas soal kemiskinan dan praktik kebijaksanaan pernikahan dalam mengendapkan persoalan konversi. Namun karena keterbatasan halaman maka artikel ini tidak membahas persoalan hukum Islam mengenai kebebasan beragama dan pindah agama.]

Keywords: apostasy, Ulama, Dutch colonial government, Vereenigde Oost-Indische Compagnie (VOC).

\section{A. Introduction}

This article focuses on the controversial issue of apostasy pertaining to the alleged family of Shaykh Yusuf of Makassar, the Indonesian pioneer of Islam in colonial South Africa, after his demise at the Cape in the late 17th century during a period of Dutch occupation of both countries. The Cape was under a first period of Dutch rule for roughly 150 years from 1652 until 1795. During this time the Cape was governed by the Dutch East India Company (DEIC) or Vereenigde OostIndische Compagnie (VOC). ${ }^{2}$ It is reported in local and international historical and scholarly sources that the second generation grandchildren of this political exile and learned Islamic scholar converted from Islam to Christianity at the Cape and thereafter entered into marriages with Christian spouses. Their mother is alleged to have been the Shaykh's

${ }^{2}$ Hereafter the DEIC, the VOC or the Company for the sake of convenience. 
daughter, Zytie Sara Marouff (alias Care Sale), and their father the Rajah or King of Tambora (alias Abulbasi Sultan), a fellow exiled countryman. The marriage between the Rajah and Zytie is alleged to have taken place shortly after his arrival at the Cape in 1698 but before the death of Shaykh Yusuf in 1699. The conversions are recorded to have taken place within two decades of the Shaykh's death and shortly after the death of their father, the Rajah, in 1719; both averted death sentences but died during exile at the Cape.

The main aim of this article is to critically analyse these sources, which contain conflicting information and ambivalent views, in an attempt to unravel the mystery surrounding the (grand) children's conversions and subsequent marriages, as well as the marriage of their parents. Although some local Muslim religious authorities (ulama) at the Cape are aware of these conversions, many are not. In fact, these conversions were overlooked in a publication on the very topic. ${ }^{4}$ Local Muslims have therefore not been fully apprised by ulama and academics of this aspect of their history because the topic is understandably also a sensitive one. There is no doubt that the conversions and all the marriages took place as they are clearly recorded in credible historical sources and church baptismal and marriage registers. The aim of this article is therefore not to dispute these facts or even that these conversions may have been a voluntary exercise and a consequence of freedom of choice. Although an analysis of some of the policies of the then Dutch colonial government which were enforced at the Cape (for example, those pertaining to interracial and interreligious marriages amid a limited religious freedom), are referred to, this article highlights that socioeconomic reasons (poverty) and practical expediency (marriage) may

3 In this article the Arabic term 'ulama' (singular 'alim') is used to refer to Muslim religious authorities and includes clerics, such as 'imam', 'shaykh' (also spelt 'sheikh'), 'moulana' or 'mufti'. For the sake of convenience, the spelling 'Shaykh' instead of 'Sheikh' is used in this article unless quoted otherwise.

4 See Muhammed Haron, "Three Centuries of NGK Mission amongst Cape Muslims: 1652-1952”, Journal of Muslim Minority Affairs, vol. 19, no. 1 (1999), p. 116. Although Haron refers to the successful conversion of one Muslim by the reverend who replaced Kalden (referred to in this article), he seems to have missed entirely the conversions and baptisms of the Rajah's children at the Dutch Reformed Church (NGK) in Cape Town. 
indeed have precipitated such conversions. A detailed critical analysis, including of the Islamic law (Shari'a) pertaining to freedom of religion and apostasy, is unfortunately beyond the scope of this article due to space constraints. However, both local and foreign academics differ as to whether the children in question were indeed the grandchildren of Shaykh Yusuf. It appears that Indonesian and other academics may have been influenced by information derived from contemporary South African scholarship regarding Shaykh Yusuf. In turn, it appears that contemporary South African scholarship may also have been influenced by early South African scholarship regarding Shaykh Yusuf.

Without detracting from the value that their research has contributed to keeping his memory alive at the Cape and in Indonesia, in the end all rely on the same Company correspondence and historical travelogues, among others, that were recorded primarily during the time when the VOC government was in charge at the Cape, though not precluding the periods of British rule. With the benefit of hindsight, and access to internet resources that may not have been available earlier, I will systemically highlight that although the sources both infer (a church record in 1726 and a reference in a travelogue of a visiting Dutch cleric, Reverend Francois Valentijn, who met them in 1705) and confirm (a Company Resolution in 1720) that Care Sale was married to the Rajah and that they were indeed the Muslim parents of the children that apostasised from Islam, none of the earliest historical sources relied on by these authors either categorically, or implicity, state that Zytie was Shaykh Yusuf's daughter. It is hoped that as a result the way will be paved for new research which may be able to dispel the speculation around the conversion of his descendants that continues to taint the standing of a man who is deemed to be a Sufi saint akin to 'a second Muhammed', and who has been transnationally recognised as a national hero in both

${ }^{5}$ See André M. Van Rensburg, "The Enigma of Shaykh Yusuf's Place of Burial", Quarterly bulletin of the National Library of South Africa., vol. 57, no. 2 (2003), pp. 70-85. Van Rensburg highlights that the Company in Batavia deemed Shaykh Yusuf to be a threat because of the extent of the love and awe that he engendered in his own people, and which was likened to that manifested by Muslims toward the Prophet Muhammad. 
Indonesia, his country of birth (1995), ${ }^{6}$ and South Africa, his country of death (2005). ${ }^{7}$ I use the information available about both families as a basis for the argument that there may be no relationship between the Shaykh and Zytie, and that therefore the Rajah was not his son-in-law. For this reason, although Zytie (or Care Sale) may indeed have been the Rajah's wife and their children had indeed apostasised from Islam, the relationship between the Shaykh as their grandfather may be contrived and based more on speculation (given that its origin can be traced all the way back to a 'hearsay' entry recorded in another travelogue of a British visitor to the Cape, Lady Duff Gordon, during a period of British rule in the 19th century) than fact, and cannot therefore be proved beyond a reasonable doubt.

I further contend that several historical sources highlighted in this article may contain clues which provide leads to information which hitherto may possibly have been overlooked, but which could further assist in challenging the prevailing view that it was Shaykh Yusuf's grandchildren that apostasised from Islam. As a consequence, it may encourage further research on this topic, and on the families of the Shaykh and the Rajah, which is beyond the scope of this article. For example, implicit from this article alone, and the inordinate amount of time that went into researching and writing it, I have encountered the following issues which are still in need of further exploration and which, if answered, may ultimately warrant a change to the article's conclusions. The Shaykh was exiled to the Cape from Ceylon (now Sri Lanka) and not Indonesia and arrived with a large entourage of 49 persons, the

6 According to information recorded on a commemorative tablet located at Shaykh Yusuf's shrine in the Cape, this occurred posthumously on 7 August 1995. Further, the then Indonesian President Soeharto also visited the Shaykh's shrine on 21 November 1997. See Schalk W. le Roux, "Die Kramat van Sjeg Yusuf, Faure", Kramat of Sheikh Yusuf (2013), n. 25, https://www.artefacts.co.za/main/Buildings/bldgframes. php?bldgid=10977, accessed 31 Mar 2020.

7 In 2005 Shaykh Yusuf was posthumously awarded the South African Order ofthe Companions of O.R. Tambo in Gold for his exceptional contribution to the struggle against Dutch colonialism. For details see "Sheik Yusuf (1626 - 1699)", The Presidency, http://www.thepresidency.gov.za/national-orders/recipient/sheikyusuf-1626-1699, accessed 31 Mar 2020. 
size of which was 'unmatched in any other case of exile to the Cape', yet, as will be detailed in Section 3, only 30 (and not 429) persons are accounted for by name in the Company Resolution dated 30 October 1699. This would imply that the rest (19) were slaves, but this number appears to be disproportionate to the number (30) actually accounted for. By the time his entourage returned to Indonesia in 1704, their number appear to have increased to 60. South African expert on Shaykh Yusuf, Professor Dangor, ${ }^{10}$ appears to still believe that only Shaykh Yusuf's male children and grandchildren below the age of five or six eventually returned to Indonesia but, as will be detailed in Section 3, while this was initially the plan, Company records indicate that the Dutch government at Batavia, persuaded by the insistence of Shaykh Yusuf's head wife Cara Contoe (also known as Khatijah or Sharifah Fatima and a daughter of Sultan Ageng Tirtayasa of Bantam) at the Cape that they all return, had eventually changed its mind and allowed them all, barring a few who chose to remain, to return to Indonesia, and that from there, the Cape government hoped, that "the whole lot, for your (Batavian government's) peace and quiet, have been sent on to Macassar". ${ }^{11}$ Although we do not know the ages of the children who arrived at the Cape, and although this also may mean that he is contradicting himself, this would explain why Dangor ${ }^{12}$ himself mentions that one of the Shaykh's sons 'Muhammad Jalal al-Din' or 'Muhammad Rajah' (referred to as 'Moehama Radja' in the Company record), who formed part of the entourage at the Cape, lies buried in Indonesia. A Company Letter despatched from the Cape in 1700 also refers to a Petition of Karakonto annexed to it which could shed important light as to whether or not Zytie (Care Sale) was indeed

${ }^{8}$ See Kerry Ward, Networks of Empire: Forced Migration in the Dutch East India Company (Cambridge: Cambridge University Press, 2009), p. 211.

9 Although according to S.E. Dangor, the number totalled 42, this will be challenged in Section 3. Suleman E. Dangor, Shaykh Yusuf of Makassar (Durban: Iqra Publishers, 1994), p. 42.

10 Ibid., pp. 48-9.

11 See Company Letter (number Eight) Despatched from the Cape, 6 April 1705, referred to in Section 3 and detailed in footnote 287. The volley of letters between Cara Contoe and the Dutch governments at the Cape and Indonesia are also detailed in Sections 3 and 5. See footnote 134.

12 Dangor, Shaykh Yusuf of Makassar, pp. 19-20. 
the Shaykh's daughter, unfortunately, it appears not to be available. We do not know if anyone has ever viewed another Annexure, referred to in the Company records (1704), and which may be located in the National Archives in The Hague, The Netherlands, which contains information of Shaykh Yusuf's departing entourage. Although the Shaykh spent almost a decade in Ceylon we have little information about this period or of the time spent at the Cape. As is also evident from correspondence (letters and documents) despatched to authorities in Batavia and received at the Cape, and referred to in this article, Dangor highlights that this could be attributed to the fact that the Company "... was concerned primarily with recording financial transactions and other official matters rather than with the lives and activities of the inhabitants of the Cape Colony at the time". ${ }^{13}$

Shaykh Yusuf spent half of his life studying and in exile. Although the Shaykh spent a mere five years in exile at the Cape before he died, his family and entourage remained at the Cape for a further five years until 1704, when they eventually returned, bringing their total time at the Cape to almost equal to their decade in Ceylon. As a consequence, his family (wives and children) spent nearly 20 consecutive years away from Indonesia. The Rajah, given that he unusually spent two periods in exile at the Cape (from 1698 to 1710 and 1714 to 1719), and who appeared to have been the only exile to have done so, ${ }^{14}$ spent a total of some 17 years in exile there. We have conflicting scholarly sources which report that when the Rajah returned to the Cape from Indonesia for the second time, some $8^{15}$ or $20^{16}$ other people, also banished from Tambora, accompanied him. Although there is no clear indication that they were, these persons are assumed by these scholarly sources to have formed part of the Rajah's entourage. We do not know if there is a list of the names of the people who may have accompanied the Rajah to South Africa for his two periods of exile there to verify that he married

13 Ibid., pp. 3-4.
14 Ward, Networks of Empire, p. 211.
15 André M. Van Rensburg, "Shaykh Yusuf's Familia", Familia, vol. 39, no. 4 (2002), p. 199; Ward, Networks of Empire, p. 211. See footnote 34.

16 Daniel Sleigh, Die buiteposte: VOC-buiteposte onder Kaapse bestuur 1652-1795 (Pretoria: Haum, 1993), p. 234. 
Care Sale in Indonesia (which is implied in a reference in the travel account of Valentijn, the visiting cleric referred to above). One of his sons returned to Indonesia in 1743 but we do not have any information as to what happened to him. ${ }^{17}$ Strangely, in the same year (1743) a call was also made for the return of the Rajah's remains. We know that this did not happen, and we are not sure if the Rajah was buried in the same the area where he last lived (Stellenbosch). We also do not know when his wife Care Sale died or where she may be buried.

The article is accordingly divided into eight sections, inclusive of this Introduction (Section 1) and the Conclusion (Section 8), as follows: Section 2 provides important clarifying information which promotes a better understanding of the general historical context of the events canvassed in the article. Sections 3 and 4 discuss the families of Shaykh Yusuf and the Rajah, respectively, in Indonesian and South African historical contexts. Section 5 provides a critical and integrated analysis of early and recent scholarly interpretations of historical resources pertaining to the two families in order to set the record straight by drawing a clear distinction between them. Section 6 revisits further clues in historical resources in support of this article's main argument that may have been overlooked. Section 7 highlights, without any detail, Government policies then in place at the Cape which may have ultimately contributed to the conversion (apostasy) of the Rajah's children.

\section{B. Clarification of The General Historical Context}

As indicated in the introduction, during their period of occupation of the Cape, the Dutch did not detail the minutiae of the family life of Shaykh Yusuf and the Rajah in their records, and therefore this section provides an important explanatory context which promotes a better understanding of these families and the events related in the rest of the article. The history of Islam in South Africa is inextricably intertwined with South Africa's history of colonialism. In the mid-seventeenth century it was Dutch colonialism which had inadvertently brought Islam to the Cape. However, the first Muslims who arrived here in 1658 were not royal or religious and high ranking influential political exiles (Orang Cayeng) like

17 Ibid. Text to footnote 320 . 
Shaykh Yusuf and the Rajah, but free persons, called "Mardyckers", ${ }^{18}$ who were brought from Ambonya, an island of the Moluccas, in Indonesia. Although the Dutch prohibited the public practice of, and conversion to, Islam, the Mardyckers were allowed to practise Islam in a private and personal manner. Shaykh Yusuf was therefore not the "founder"19 of Islam at the Cape, as some South African ${ }^{20}$ and Indonesian ${ }^{21}$ scholars have misleadingly argued to be the case. Although his five-year stay at the Cape was short-lived, he is still celebrated as one of the earlier pioneers and revivers of Islam there. As will be detailed in Section 3, given his scholarly credentials at the time, he was undoubtedly also among the most educated men to have arrived at the Cape. As detailed in Section 3, Islam in South Africa survived two periods each of Dutch and British colonial rule, and rule by an apartheid regime (from 1948 to 1994), and is still flourishing there after more than 350 years. South African Muslims have likened Shaykh Yusuf to local struggle icon, former President Nelson Mandela, because of his role in the revival of Islam in South Africa and for sacrifices as a political exile. Both spent periods of isolation in their own countries, but unlike Mandela, Shaykh Yusuf was allowed to bring his family with him to Ceylon and South Africa during his periods of exile there. After the attainment of democracy in 1994, diplomatic links between the two countries was also re-established. The

18 Ebrahim Mahomed Mahida, History of Muslims in South Africa: A Chronology (Durban: Arabic Study Circle, 1993), p. 1. For detail, see Section 7 below.

19 See text to footnote 23 below for an explanation. Abdulkader I. Tayob, Islam in South Africa: Mosques, Imams, and Sermons (Gainesville: University Press of Florida, 2009), pp. 22-3.

${ }^{20}$ For example, this is implicit in the title of Chris Greyling, "Schech Yusuf, the Founder of Islam in South Africa", Religion in Southern Africa, vol. 1, no. 1 (1980), pp. 9-22.

21 Indonesian authors who mistakenly also call him "founder" include Nabilah Lubis, "Min A'lāmi Indūnīsīya: al-Shaykh Yūsuf al-Makassarī (1626-1699)", Studia Islamike, vol. 1, no. 3 (1994), p. 150; Azyumardi Azra, The Origins of Islamic Reformism in Southeast Asia: Networks of Malay-Indonesian and Middle Eastern 'Ulama' in the seventeenth and eighteenth centuries (Crows Nest, NSW: Allen \& Unwin, 2004), p. 102. More accurately, uses the terms 'reviver' or 'revitaliser' to describe his role in this regard. 
$1994^{22}$ Tricentenary Commemoration of the establishment of Islam was based on the date of his arrival at the Cape in 1694, rather than that of the Mardyckers, who first came there in 1658. ${ }^{23}$ Although Muslims are a religious minority in South Africa, the current Constitution (1996) ${ }^{24}$ guarantees everyone the right to freedom of religion and belief.

The Western Cape continues to have the largest Muslim community in South Africa. Shaykh Yusuf has also formally been recognised as a national hero in both the Republics of Indonesia (his place of birth) and South Africa (his place of death). The area in which Shaykh Yusuf died, and where he was also initially buried, until his bodily remain $\mathrm{s}^{25}$ may

22 In 1994 South African Muslims celebrated what was deemed to be the tercentenary of the presence of Islam at the Cape. See Shamil Jeppie, "Commemorations and Identities: The 1994 Tercentenary of Islam in South Africa", in Islam and the Question of Minorities, ed. by Tamara Sonn (Atlanta, Ga: Scholars Press, 1996), pp. 73-91.

${ }^{23}$ For details see Tayob, Islam in South Africa.

24 South African Government, The Constitution of the Republic of South Africa, sec. 15 verse 1.

25 It appears from a Company letter (dated 14 June 1704) to the authorities in Batavia, detailed in footnote 327, (in response to a Company letter dated 26 February 1704), received at the Cape detailed in footnote 326, that the Cape government was prepared to turn a blind eye should the remains of the Shaykh be exhumed for this purpose. In 1704 his remains were allegedly repatriated to Indonesia with his family. Shortly after their arrival in April 1705, his remains were reburied in his hometown. Divergent reports speculate that when his remains were exhumed, either only one finger was left behind at the Cape or only a handful of dust from the remains of his finger was taken to Indonesia. For details see Azra, The Origins of Islamic Reformism in Southeast Asia, p. 103; Van Rensburg, "The Enigma of Shaykh Yusuf's Place of Burial”, p. 70; Dangor, Shaykh Yusuf of Makassar, p. 59. Cape Historian Ebrahim Salie is of the opinion that the remains of Shaykh Yusuf may indeed have been returned to Indonesia. Mr Salie has provided me with the references to sources (all dated 1704) from the National Archives in The Hague, The Netherlands, in support of this view. (Personal communication, 18 April 2020). There are cases which would corroborate Salie's view and sources. For example, Ward, Networks of Empire, p. 221. He refers to the body of an Indonesian prince being "disinterred and taken home for burial" around 1735, some 30 years after the departure of Shaykh Yusuf entourage in 1704. Nonetheless, Ms Keke Parawansa, the Indonesian descendant of Shaykh Yusuf referred to in this article, strategically offers a more balanced opinion. She avers that the Shaykh's bodily remains may be both in Cape Town and Indonesia because a Muslim burial would traditionally have warranted a quick burial at the place of death (the Cape) but the fact that he was a Sufi saint would explain the mystery of his bodily remains also being witnessed by people 
have been relocated to Gowa in Sulawesi, Indonesia, has been renamed "Macassar" in honour of his place of birth. As will be detailed in Section 4 (dealing with the Rajah), Valentijn's account mentions his visit in 1705 to what can be described as the rudimentary grave site of Shaykh Yusuf "... with an ornamental Moslem tomb, built up very high of stones." The place in which he lies buried called a "kramat", ${ }^{26}$ was only built much later in the 19th century. ${ }^{27}$ "A shrine was constructed over his grave. Over the years this shrine has been rebuilt and renewed. Today it remains a place of pilgrimage ". ${ }^{28}$ It was reported in May 2019 that an application to have such burial places, including his, declared national heritage sites by the South African government, was in the process of being considered. ${ }^{29}$ The graves of his four followers are also located near his grave. ${ }^{30}$ In 1829 , a visitor to the Cape wrote of the kramat as the place where "...

in Gowa, Sulawesi when his 'coffin' was opened there after its arrival from the Cape. (Personal communication, 20 April 2020).

26 Some 23 graves of prominent pioneers of Islam are strategically located in Cape Town and surrounding areas. Their burial places are labelled 'kramats'. The grave of Sheikh Yusuf is one of them. For details see Mansoor Jaffer (ed.), Guide to the Kramats of the Western Cape, 3rd edition (Cape Town: Cape Mazaar Kramat Society, 2010), pp. 16-8. A visionary philanthropist and businessman, Sulaiman Shah Mahomed, who left a legacy of reconstructed shrines and mosques at the Cape, sponsored the reconstruction of Shaykh Yusuf's shrine in 1927. Sulaiman Shah Mahomed was born in in India in 1859. He later settled at the Cape where he married 'Rahima Salie, daughter of the respected fish-monger and basket-maker, Slemmon Salie' and where he later also died in 1929 just before witnessing the completion of Shaykh Yusuf's shrine. For details on his generous contribution to 'culture conservation' at the Cape see M.T. Ajam, “Hajee Sulaiman Shah Mohamed: A South African Philanthropist (d. 1929)", Journal for Islamic Studies, vol. 10 (1990), p. 68.

27 Dangor, Shaykh Yusuf of Makassar, pp. 50-1.

28 Jaffer (ed.), Guide to the Kramats of the Western Cape, p. 18.

29 Francesca Villette, "31 Kramats Considered for Heritage Status", IOL (3 May 2019), https://www.iol.co.za/capetimes/news/31-kramats-considered-forheritage-status-22404699, accessed 31 Mar 2020.

30 Dangor, Shaykh Yusuf of Makassar, pp. 56-7. The following is information is inscribed on a pillar adjacent to their graves: "HERE LIE THE REMAINS OF FOUR OF FORTY-NINE FAITHFUL FOLLOWERS WHO AFTER SERVING IN THE BANTAM WAR OF 1682-83, ARRIVED WITH SHEIKH YUSSUF AT THE CAPE FROM CEYLON, IN THE SHIP ‘VOETBOOG’ IN THE YEAR 1694”. See footnote 129 . 
Malays...have a grand annual festival, which lasts for three days...". 31 This tradition, akin to a religious 'pilgrimage', continues at both the Cape and in Indonesia, ${ }^{32}$ where it appears that his remains (or part of it) may subsequently have been reburied.

Shaykh Yusuf died 'on Thursday night come Friday, 22 or 23 May $16999^{33}$ As will be indicated in Section 3, given that it is not certain whether he was born in 1626 or 1627, he is deemed to have died at the age of either 73 or 74 . It is also not certain on what day he died. Some sources say he died on a Thursday and some say he died on a Friday. However, he appears to have died on a Thursday night, which would have warranted an Islamic burial the next day (Friday). Friday is regarded as an auspicious Islamic holy day, the night of which starts on Thursday after sunset. At the Cape his death on a Thursday night would therefore have been deemed to have been a good omen given that it heralded an auspicious Friday burial.

Unfortunately, the Rajah's fate, and that of his family, took an altogether different turn. The Rajah, who ruled Tambora from 1687 to

31 Jackie Loos, Echoes of Slavery: Voices from South Africa's Past (Cape Town: David Philip, 2004), p. 48.

32 Grave visits are a very common practice in Indonesia and have been even before the advent of Islam there. With the spread of Islam there, and conversions to Islam, this local tradition continued to be practised and, blended with Islamic teachings on the significance of praying for the salvation of dead relatives, was extended to include honouring saints, noble persons or ulama. While the year or decade is uncertain, it appears to have started when Islam was brought to Java in the $15^{\text {th }}$ century by nine saints of Sufi background, called 'Wali Sanga' or 'Wali Songo', who were probably Arab traders from India, and who died and were buried in Indonesia. The re-burial place of Shaykh Yusuf in Makassar, Indonesia, is one such destination. This information was gleaned from Personal communication with Prof Euis Nurlaelawati, 7 March 2020. For further detail see George Quinn, "Where History Meets Pilgrimage: The Graves of Sheikh Yusuf Al-Maqassari and Prince Dipanagara in Madura", Journal of Indonesian Islam, vol. 3, no. 2 (2009), pp. 249-66; Duncan Graham, “'Bandit Saints of Java': Where Islam meets Local History”, The Jakarta Post (15 Mar 2019), https:/ / www.thejakartapost. com/life/2019/03/14/bandit-saints-of-java-where-islam-meets-local-history.html, accessed 31 Mar 2020. See footnote 94 for more detail on pilgrimages.

33 Van Rensburg, "Shaykh Yusuf's Familia”, p. 196; Van Rensburg, "The Enigma of Shaykh Yusuf's Place of Burial", p. 75. Ibid., p. 84. Note 53 also points out that some sources state Friday 23 May to be his date of death. See Dangor, Shaykh Yusuf of Makassar, p. 48. 
1697, was later deposed and stripped of his title. He died in South Africa during a second period of exile which was very different from his first. According to Sleigh:

...(w)ith the down fall of (Willem Adriaan) Van der Stel, and his departure from the Cape (1708), the Rajah and his family were relocated (from the Governor's plush Vergelegen estate in rural Stellenbosch) to the (Company) outpost, Rustenburgh (located in present-day Rondebosch and nearer to central Cape Town)...The Rajah ... and other Eastern exiles obtained amnesty in $1710 \ldots$...but...exiled him back to the Cape in 1713 with his retinue of $20^{34}$ persons. The Rajah resided until 1720 (died in late 1719), thereafter, in dire poverty in Stellenbosch, where he passed away. In 1743, a petition reached (the Cape) from the East India, that his remains must be returned to the East, which reflected that he was held in high esteem. ${ }^{35}$

We can infer from a Company Resolution ${ }^{36}$ that Rustenburg had fallen into disuse upon the Rajah's return from Indonesia in 1714. The Resolution corrobates Sleigh's information that the Rajah stayed in Stellenbosch where he also died in 1719.

There were two periods each of Dutch and British occupation

34 As indicated, according to K. Ward and A.M. Van Rensburg, there were eight not 20 persons. See footnote 15 above.

35 Sleigh, Die buiteposte, p. 234. I wish to express my appreciation to Mr E Rhoda for referring me to this source. I would like to acknowledge that the paragraph in Sleigh's book quoted above was extracted from the translation by independent slave historian, M.G. Kamedien, "Raja of Tambora \& Joseph at Macassar", rootsweb (6 Nov 2001), https://lists.rootsweb.com/hyperkitty/list/south-africa@rootsweb.com/ thread/11320360/, accessed 31 Mar 2020. See footnote 162.

36 "Nacoda Lelo Pangoela Moars, and Rajo Nassatie, 1717 sent hither from India some years ago, and located at the other side of the Salt River, at the place called the 'Ruijterstal,' where they have hitherto lived; but they were obliged to leave that place, in order to make room for the workmen making the mill there, and have no other place where to live; they therefore request permission to locate themselves on the place formerly occupied by Tambora, now for many years unoccupied. (No. 91.)" See H.C.V. Leibbrandt, Precis of the Archives of the Cape of Good Hope: Requesten (memorials) 1715-1806, vol. 2 (Cape Town: Cape Times, 1905), p. 829. Available at "Ebook Precis of the archives of the Cape of Good Hope (Volume 17) by Cape of Good Hope (South Africa)", ebooksread, http://www.ebooksread.com/authors-eng/cape-of-good-hopesouth-africa-archives/precis-of-the-archives-of-the-cape-of-good-hope-volume-17-ala. shtml, accessed 31 Mar 2020. 
of the Cape. The first period of Dutch rule, from 1652 to 1795, lasted for 150 years. This was followed by two periods of British occupation, the first from $1795^{37}$ to 1803 and the second from 1806 to the end of the nineteenth century (except for a short second period of Dutch rule from 1803 to 1806). It is important to put these periods in historical perspective, because the negative impact that Dutch policies had on the reputations of the Rajah and Shaykh Yusuf continued long after their demise and into the next period of colonial rule. While both the Shaykh and the Rajah, and their respective families, were resident at the Cape only during the first period of Dutch rule, which had ended long after the two had died in exile there, some of the scholars referred to in this article, increduously, rely on a source (1861 travelogue) dated during a period of British rule, which had initiated the 'rumour' that the Rajah was married to the Shaykh's daughter. As detailed in Section 7, two entries in this travelogue highlight that even though it was during the second short period of Dutch rule that religious freedom was first granted in 1804, its practical implementation was still being hampered during the second period of British rule.

Indonesia, known for its spice islands, was also strategically located on the spice trade route over which the Dutch was trying to secure monopoly with other parts of Asia. ${ }^{38}$ For the VOC, the shores of the Cape served as a strategic midpoint on the trade route between its headquarters in Amsterdam in The Netherlands, and Batavia (presentday Jakarta located on the island of Java) as follows:

... The Cape was strategically very well placed along the trade route between the Netherlands and Asia...to (replenish) ships. In order to secure this advantage to itself the...VOC...established a settlement in 1652 and built a fort (Castle of Good Hope). The initially small settlement... when the VOC rule came to an end in $1795 \ldots$ had become a large colony. ${ }^{39}$

37 The British took over from the VOC government at the Cape on 16 September 1795. See Helena Liebenberg, Introduction to the Resolutions of Cape of Good Hope (Cape Town: TANAP), p. 39.

38 See "Dutch East India Company (DEIC)/VOC", South African History Online, https://www.sahistory.org.za/article/dutch-east-india-company-deicvoc, accessed 31 Mar 2020.

39 Liebenberg, Introduction to the Resolutions of Cape of Good Hope, p. 4. 
During the first period of Dutch rule, two successive father (Simon van der Stel) and son (Willem Adriaan van der Stel) Governors at the Cape and two young clerics, both Dutchmen in the employ of the Company, Reverend Petrus Kalden, at the Cape, and Reverend Francois Valentijn, in Indonesia, are referred to in this article in the context of Shaykh Yusuf and the Rajah and therefore it is useful to place their roles and backgrounds in an explanatory historical context.

Simon van der Stel was the last Commander (official who headed the government) of the colony from 12 October 1679 to 1 June 1691 . He subsequently became the first Governor at the Cape from 1 June 1691 to 11 February 1699. His son, Willem Adriaan van der Stel, succeeded him as Governor from 11 February 1699 to 3 June $1707 .{ }^{40}$ Unlike his father who resigned from his position, Willem Adriaan was dismissed from his position as Governor and returned to The Netherlands. Given these dates, and their overlapping terms, Simon was Governor when both Shaykh Yusuf (1694) and the Rajah (1698) arrived at the Cape. His son, Willem Adriaan, was Governor by the time the Shaykh died at the Cape in 1699, when the Shaykh's entourage left in 1704; and when the Rajah resided at Vergelegen (Willem Adriaan's residence) in 1705, but was no longer Governor by the time the Rajah was pardoned in 1710 and returned to Indonesia.

Simon van der Stel was born on 14 October 1639 and died at the Cape on 24 June 1712 at the age of $72 .{ }^{41} \mathrm{He}$ was therefore 55 years old when the Shaykh, then aged 67 or 68, arrived (in 1694) and the Rajah, who arrived some four years later (in $1698^{42}$ ), was then 28 years old. The age gap (some 10 years) between Simon and the Shaykh was much smaller than the large (some 27 years) age gap between Simon (who was old enough to be his father) and the Rajah. After Simon retired as Governor in 1699, he spent his time at his estate called 'Groot Constantia' which was located in Constantia, near central Cape Town. Willem Adriaan was

40 Ibid., p. 34.

41 See background to "Simon van der Stel", Wikipedia, https:/ / en.wikipedia. org/w/index.php?title=Simon_van_der_Stel\&oldid=954229072, accessed 31 Mar 2020.

42 Ward, Networks of Empire, p. 210. Note 113. As detailed in Section 4, although it was resolved in 1697 to exile the Rajah to the Cape, he only arrived there in 1698. See footnote 164 . 
born in 1664 and was therefore 35 years old when he became Governor in 1699 and the Rajah was 29 years old. It made practical sense that given his status, and the similarity in their ages, that the Rajah would be housed with Willem Adriaan at Vergelegen. In 1705, when Valentijn (one of the two clerics referred to above), then aged 39, met the Rajah at Vergelegen on a visit there, the Rajah was 35 years old, his wife, whom we, with hindsight, know was named Care Sale, was 26 years old, the Governor was 41 years old and Petrus Kalden (alias Calden), the other Reverend referred to, and who was based at the Cape, was also 35 years old. There therefore was not much of an age difference between the men.

Simon, like the Rajah's grandchildren, as will be detailed in Section 7 , was also of mixed ancestry and had moved to Batavia in his teens and remained there until the age of twenty. ${ }^{43}$ Simon, therefore had to be familiar with, and knowledgeable of, the culture and religion of Indonesian Muslims, and must also have had a considerable influence in preparing his son Willem Adriaan for the position of governor. The Cape was also not unfamiliar to Willem Adriaan. Willem Adriaan was 15 years old when he first came to the Cape with his father in 1679 and where he remained until the age of 20 when he returned to Holland in 1684. While it may also have been customary for VOC officials to be accompanied to Company outposts with their families, in Simon's case his relationship with his Dutch wife was strained and therefore her sister accompanied him to the Cape instead. I am not sure whether Willem Adriaan's Dutch wife had accompanied him to the Cape but they had five children. Given that his mother was not at the Cape, may in part explain why the Rajah's wife would have an oversight housekeeping role at his homestead in Vergelegen. ${ }^{44}$ Given Simon's familiarity with Indonesian Islam, it is not surprising that both father and son appeared to have developed close (possibly closer than may have been expected by the Company in Batavia)

43 See Melletpt, "The Story of the First Two 'Coloured' Governors at the Cape - Simon \& Willem”, Camissa People (17 May 2016), https://camissapeople. wordpress.com/2016/05/17/the-story-of-the-first-two-coloured-governors-at-thecape-simon-willem/, accessed 31 Mar 2020; J.B. Bedaux, "The portraits of Simon van der Stel, first governor of the Cape", Stellenbosch Papers in Linguistics, vol. 17 (1988), pp. 3-7.

44 See "Simon van der Stel"; "Willem Adriaan van der Stel", Wikipedia, https://en.wikipedia.org/w/index.php?title=Willem_Adriaan_van_der_ Stel\&oldid=951526567, accessed 31 Mar 2020. 
respectable relationship ties with the Shaykh and the Rajah, who were both probably treated with more religious tolerance and sensitivity than the other such high ranking or influential political exiles also there at the time, with due deference to their royal and religious social standing, than would ordinarily have been expected under the circumstances then prevailing at the Cape.

Valentijn was born on 17 April 1666. He was in the employ of the Company in Indonesia where he spent some 16 years and visited the Cape at least four times (in 1685, 1695, 1705 and 1714) en route to Indonesia from The Netherlands and back, as follows:

In February 1685 he sailed for the East...staying at the Cape of Good Hope for 30 days... (In Indonesia) (h)e became fluent in Malay and in 1689 started to translate the Bible and other religious works into Low Malayan... Valentijn returned to the Netherlands in 1695, after again touching at the Cape, this time staying for 51 days... In May 1705 he returned to the East in the service of the Dutch East India Company and visited the Cape for the third time, for 39 days $^{45}$.... After some time at Batavia (now Jakarta) he returned to the Netherlands in 1714, spending 70 days at the Cape on his fourth visit. ${ }^{46}$

According to Sleigh, ${ }^{47}$ during Valentijn's first visit in 1685 he (then aged 19 and newly ordained) was a guest of then Governor Simon van der Stel at a Company outpost called Rustenburg (located in present-day Rondebosch). During a second visit ten years later in 1695 at the age of 29, the Governor's son Adriaan (then 31 years old) acted as his host at Rustenburg. The visit occurred a year after the Shaykh's arrival but no indication is given that he may have met the Shaykh. Rustenburg was also used by these successive governors as an official residence. The Cape, according to Sleigh, was plagued by drought and Rustenburg had

45 "Valentijn arrived at the Cape on the ship 'Jjpendam' on 29 September and departed on 7 November 1705”. See Van Rensburg, “The Enigma of Shaykh Yusuf's Place of Burial", p. 82.

46 See C. Plug, "Valentijn, François (geography)", S2A3 Biographical Database of Southern African Science, http://www.s2a3.org.za/bio/Biograph_final.php?serial=2901, accessed 31 Mar 2020.

47 This section was extracted from Daniel Sleigh, "Die buiteposte van die V.O.C. aan die grens van die Kaapse nedersetting, 1652-1707”, Master Thesis (Stellenbosch: Stellenbosch University, 1982), pp. 138, 142-5, 150. 
a problem with locust infestation, but Governor Simon was reluctant to close down this outpost in 1695 and did not do so when instructed by the Company. Sleigh indicates that this may explain why the name Rustenburg does not appear on the list of occupied posts in 1705 and why, after Governor Adriaan was dismissed in 1707, Rustenburg also did not appear on the list of outposts in the years 1708-1710. In 1699 Adriaan, as Governor, was in charge of Rustenburg, by which time the Rajah had arrived at the Cape (1698). Valentijn in his account highlights that Willem Adriaan's Vergelegen was built between 1700-1701. Sleigh ${ }^{48}$ mentions that Valentijn had also paid another visit to Rustenburg during his third visit to the Cape ten years later in 1705 (a year after the departure of Shaykh Yusuf's entourage in 1704) and had reported that there was still activity there. This visit to Rustenburg probably also occurred before Valentijn visited Vergelegen because he departed from the Cape some two days after his visit to Vergelegen. Upham ${ }^{49}$ highlights that the Dutch Reverend Petrus Kalden was born in 1670 (in the same years as the Rajah) and died in 1739. He arrived at the Cape in 1695 as Calvinist preacher and minister of the Dutch Reformed Church. He was granted the farm Zandvliet located in the 'Cape Dunes (near the present-day Faure) in the district of Stellenbosch' on 4 January 1699 but sold it on 1 March 1708, after his ministerial services were summarily terminated in 1707 . The houses in which Shaykh Yusuf lived were also sold in $1707 .{ }^{50}$ Kalden then departed from the Cape on 23 April 1708. The VOC dismissed Willem Adriaan in 1707 and he also left the Cape in 1708. Kalden and Willem Adriaan were both dismissed for colluding activities unrelated to their job descriptions. ${ }^{51}$ In 1710, three years after Willem Adriaan's dismissal, Vergelegen was sold. The Rajah was also pardoned in 1710.

Shaykh Yusuf (then aged 67 or 68) and his entourage departed from Ceylon on 23 January 1694 and arrived at the Cape on 16 April 1694 where

48 Ibid., pp. 144-150.

49 Mansell George Upham, "At war with Society ... Did God hear? The curious baptism in 1705 of a 'Hottentot' infant named Ismael”, Capensis, vol. 4 (2000), pp. 30-1, 40, 42.

50 Dangor, Shaykh Yusuf of Makassar, p. 49.

51 For details see H.C.V. Leibbrandt, Precis of the Archives of the Cape of Good Hope: The Defence of Willem Adriaan van der Stel (Cape Town: W. A. Richards \& Sons, 1897), p. 53, http://archive.org/details/precisofarchives00leib, accessed 31 Mar 2020. 
he was received by Governor Simon van der $\mathrm{Ste}^{52}$ who initially located the Shaykh and his entourage at the Castle ${ }^{53}$ in central Cape Town. His entourage included polygynous wives, concubines and slaves. It appears that the Dutch authorities were turning a blind eye to these practices, which were all condoned in terms of certain intepretations of Islamic law, as long as they were contained to occur only among these high ranking exiled families. Apart from slavery, ${ }^{54}$ these practices were against Dutch law. Given the size of the Shaykh's entourage (which was large enough to constitute an extended 'family' or an Islamic congregration), it was decided on 14 June $1694,{ }^{55}$ nearly two months after his arrival at the Cape, to relocate them to the outskirts of Cape Town to an old Company station adjacent ${ }^{56}$ to Reverend Kalden's farm. This is confirmed in a Company Resolution from which it can be inferred that his wife Cara Contoe, given her royal lineage as a daughter of a Sultan, was deemed to be accorded the status of 'headwife'. ${ }^{57}$ This station is the present-day

52 Van Rensburg, "The Enigma of Shaykh Yusuf's Place of Burial”, p. 75. See footnotes 110, 111 and 112 for conflicting dates of arrival.

53 Ward, Networks of Empire, p. 208; Upham, "At war with Society . . . Did God hear? The curious baptism in 1705 of a 'Hottentot' infant named Ismael”, p. 43; Achmat Davids, The Mosques of Bo-Kaap: A Social History of Islam at the Cape (Cape Town: South African Institute of Arabic and Islamic Research, 1980), p. 37. See footnote 57.

54 Slavery, condoned during the first VOC period, was only abolished at the Cape (then a British colony) in 1834, although it was only a few years later (in 1838) that slaves were formally emancipated there. See Loos, Echoes of Slavery, p. 7; "Slavery and Emancipation of Slaves", South African History Online, https:/ /www.sahistory.org. za/article/slavery-and-emancipation-slaves, accessed 31 Mar 2020.

55 Dangor, Shaykh Yusuf of Makassar, p. 43.

56 Many writers erroneously indicate that Shaykh Yusuf both lived and was buried at Zandvliet. However, Van Rensburg in his article on Shaykh Yusuf's family rectifies this misperception with a detailed explanation. See Van Rensburg, "Shaykh Yusuf's Familia", p. 196.

57 “The Council of Policy convened on 14 June 1694 with Simon van der Stel. Of interest to the Macassarese Priest, Schjegh Joseph, [1 Schjegh Joseph (16261699), brother of the King of Goa at Makassar and married to the daughter of the Sultan of Ageng in Bantam (Yusuf) was a sworn enemy of the Company. In 1684 he was banished to Colombo and sent to the Cape in 1693, where he arrived with the Voetboogh with a following of 49 persons and taken into custody for the first time (initially) in the Castle....] and regarding maintenance, it has been found proper that he 
Macassar (named after his place of birth) in Faure. He died there on 22/23 May 1699, some five years later, and was buried on a hilltop where, as indicated, a Kramat and shrine was subsequently built in his honour. As is also evident from the Company correspondence referred to in this article, his entourage remained there till 1704 when they finally returned to Indonesia, possibly with his remains. While it is subject to dispute whether or not Shaykh Yusuf still lies buried in his original burial site at Macassar, what appears to be undisputed is the fact that he was buried there from May 1699 to October 1704 when his remains possibly were exhumed for purposes of reburial in Indonesia.

Given their isolation, whether there may have been any contact between the Shaykh and the Rajah, or between him and the Dutch Reverend, Petrus Kalden, is anyone's guess. Van Rensburg makes the following very interesting observation:

One wonders whether this Calvinist preacher and the Muslim leader ever met. It is very likely, since there was an overlap in time and the geographical proximity of Zandvliet. ${ }^{58}$

Although Shaykh Yusuf and Kalden were neighbours, Kalden only moved there in January 1699, some four months before the Shaykh passed away, and was only 29 years old when the Shaykh died at the age of 73 or 74 . Given that they were only neighbours for a very short while, there appears to be no proof that they met each other or, given the age and religious stature of the Shaykh, that Kalden if he had tried could have influenced him to leave his faith. While Kalden was also able to do so without breaking any law, the reverse did not apply to Shaykh

has been sent along with his followers to the mouth of the Eersterivier (Eerste River at False Bay, more precisely adjacent to farm Zandvliet, in Faure, Macasser) and that we provide him, pursuant to the written order of the government of India...with a monthly allocation of $12 \mathrm{R}$ (probably Rijksdaalders, or rix dollars, the currency used at the Cape) so that he can pay a limited amount (as much as is required) to his followers, but not more than is needed for her/their subsistence." See Resolutions of the Council of Policy of Cape of Good Hope Cape Town Archives Repository, South Africa, Reference code: C (1694), http://databases.tanap.net/cgh/make_pdf.cfm?artikelid=21548, accessed 31 Mar 2020. I used Google translate to translate the first part of this Resolution and would like to thank Professor F du Toit for assistance with the last part of the free translation of this extract. See text to footnotes 237 and 53.

58 Van Rensburg, "Shaykh Yusuf’s Familia", p. 196. 
Yusuf because he was isolated and the prevailing policies prohibited him from prosethelysing. It is not unlikely that the Shaykh would have wisely adopted the following advice contained in the Qur'anic injunction "( $\mathrm{f}$ ) or you is your religion, and for me is my religion", ${ }^{59}$ rather than face the death penalty for infringement of the law.

In 1909, Colvin ${ }^{60}$ a historian, imagined the relationship between the Shaykh and Kalden as follows:

Calden, who wrote Latin verses, and may therefore be supposed to be a man of education, no doubt treated him like a gentleman, and we may imagine them debating on the merits of their religions.

If Kalden did not know Shaykh Yusuf during his lifetime, it appears that he may have known of him after his death. We can glean this from the account of the visiting Dutch clergyman, Reverend Francois Valentijn, in which he made reference to Shaykh Yusuf's burial site after paying Reverend Kalden a visit at Faure in $1705 .{ }^{61}$ As will be detailed in Section 5, Valentijn was also aware of Shaykh Yusuf's political role in Indonesia.

During his third visit to the Cape in 1705, Valentijn both paid homage at the gravesite of Shaykh Yusuf when visiting Kalden (then aged 35) on his farm, and when he also met the Rajah of Tamborah and his unnamed wife at then Governor Willem Adriaan van der Stel's estate 'Vergelegen' (literally translated as 'situated far away') where they were residing. Referring to Willem Adriaan's extravagant estate Vergelegen: “...the Governor mentioned has built, about twelve hours distant from the Cape, a country seat, large beyond measure, and of such broad dimensions, as if it were a whole town". ${ }^{62}$ Valentijn was invited as a friend of the Governor whom he accompanied him there from the Castle located in central Cape Town. In Section 4 the entry in

59 Qur'an, 109: 6. Islam has two primary sources, namely the Qur'an (the holy book of Islam) and Sunna (traditions of Prophet Muhammad). The salutation 'Peace Be Upon Him' (PBUH) to the Prophet Muhammad will, for the sake of convenience, be implied but not repeated every time his name is used in the text.

${ }^{60}$ Ian D. Colvin, Romance of Empire South Africa (London: Caxton Pub. Co, 1909), p. 170.

61 See. Van Rensburg, “The Enigma of Shaykh Yusuf’s Place of Burial”, p. 71. See foonote 183 for reference to the entry in Valentijn's account.

${ }^{62}$ Leibbrandt, Precis of the Archives of the Cape of Good Hope: The Defence of Willem Adriaan van der Stel, p. 53. See foonote 181 for reference to the entry in Valentijn's account. 
Valentijn's account indicates that the same journey, undertaken at a very high speed and with a change of horses midway, took half this time (six hours). Vergelegen, situated in Stellenbosch, was located not too far from Macassar. However, like Faure (the location of Shaykh Yusuf's home in Macassar), Vergelegen was also located on the outskirts of the city. Today a trip to Cape Town from there will be a mere half hour's journey by car, but at the time was probably a whole day's journey by horse and cart. In Section 4 the entries in Valentijn's account, including one which has hitherto played a significant role in upholding the prevailing view that the Rajah was married to the Shaykh's daughter, are revisited and analysed with a view to setting the record straight and to highlight other information it may contain relating to the Shaykh and the Rajah.

It will become apparent from this article that when Valentijn met the Rajah at Vergelegen in 1705, he was busy transcribing the Qur'an (the primary source of Islam which was revealed in Arabic) by hand. It does not appear from his account of the Cape that their paths crossed again during his fourth trip in 1714, when the former Rajah may have returned from Indonesia to serve a second period of exile at the Cape. However, as indicated, Valentijn is reported as having paid a visit to another son (and brother of Willem Adriaan) of Simon van der Stel at his estate in Constantia in March 1714. The estate was sold in $1716 .{ }^{63}$ The Shaykh, despite his credentials as a scholar and prolific writer and author of several academic books ${ }^{64}$, does not, after he left Ceylon for the Cape, appear to have written any further books ${ }^{65}$ or to have recorded an account of his five-year exile at the Cape. This could either be attributed to his age, failing health ${ }^{66}$ or that he may not have been allowed to do so. In any

${ }^{63}$ See background to "Simon van der Stel".

64 Azra, The Origins of Islamic Reformism in Southeast Asia, p. 188. At its note 62, writes that: "(o)f about 29 works attributed to (him)...no fewer than eight were written in Srilanka".

${ }^{65}$ Ibid., p. 101. He writes that “...there is no evidence that (Shaykh Yusuf)... spent his time on writing (in South Africa), for none among his known works contains any indication whatsoever that it was written in South Africa."

66 S. Jappie, in her recently completed thesis on Shaykh Yusuf, provides rare insight into the state of his health already some five years before he was transferred to the Cape in an extract from a "( $\mathrm{t}$ )ranslation of a Malay letter from Sjeech Josuff Tadja sent from Ceylon to Batavia, 19 February, 1689” as follows: "I, Shaykh Yusuf, am weak 
event, as will be highlighted in Section 3, the Shaykh had memorised the Arabic Qur'an (hafiz) ${ }^{67}$ and therefore, figuratively speaking, always had it on his "person" and moreover "wrote his works in perfect Arabic" ${ }^{68}$ Although he was fortunate to be allowed to receive parcels ${ }^{69}$ at the Cape, which were forwarded to him from Ceylon where he had previously been held in exile, their contents are unknown but probably included products from Indonesia, like textiles for his Sufi garb, or longed-for food items, like spices. ${ }^{70}$ Nonetheless, the parcels would probably have been intercepted and any items, especially books, that could have been

and in a despicable state, moreover so old that it is difficult for me to stand for a long time... It thus pains me to dwell with such grief and discontent in a strange land..." Saarah Jappie, "Between Makassars: Site, Story, and the Transoceanic Afterlives of Shaykh Yusuf of Makassar", PhD. Dissertation (Princeton, N.J: Princeton University, 2018), p. 30. However, she does caution that "... it is a Dutch translation of the original Malay letter that is yet to be found." Ibid., p. 47. For the full text of the translation and her analysis thereof see Jappie. Ibid., pp. 47-48. The climate at the Cape, with it cold, wet winters was also very different from the warm, tropical climates in Indonesia and Ceylon.

67 'Hafiz' is the Arabic term used to describe a person who has memorized the entire Qur'an which consists of 114 Surah and over 6000 verses.

68 Azra, The Origins of Islamic Reformism in Southeast Asia, p. 103.

${ }^{69}$ H.C.V. Leibbrandt, Precis of the Archives of the Cape of Good Hope: Letters received, 1695-1708 (Cape Town: W.A. Richards \& Sons, 1896), p. 10, http:/ /archive.org/ details/precisofarchives00cape_3, accessed 31 Mar 2020. Letter Number One Received at the Cape, 14 January 1695: "No. 4, p1 from Colombo (Ships affairs, particulars about the Ceylon squadron and its cargo.) Since the departure of the Mahometan priest Sheik Joseph, we received for him three parcels sent with these ships, and which are to be delivered to him." Extract from minutes of the Batavia Court of Justice, dated 26th August, 1695.

${ }^{70}$ My assumption is based on the several images of Shaykh Yusuf in which he is dressed in garments (turbans and capes) traditionally worn by Sufis. Indonesia was on the spice route and certain spices which originated from there, like cloves, nutmeg and pepper, was used in traditional foods and had certain medicinal properties. For example, much like chewing tobacco, Shaykh Yusuf was known for chewing betel nut which is the seed (fruit) of the areca palm grown in Southeast Asia and South Asia. Slices of the seed is wrapped with a little lime and spices in a peppery tasting betel leaf. See Ward, Networks of Empire, p. 205. It is still a customary practise in Indonesia (as in India and Sri Lanka) to chew betel nut. However, it is currently discouraged (banned or prohibited) in some areas in Indonesia because of the mess it leaves behind when people spit it out after chewing it. For details see "Areca nut", Wikipedia, https:/ / en.wikipedia. org/w/index.php?title=Areca_nut\&oldid=968036123, accessed 31 Mar 2020. 
deemed controversial, would have been censored and confiscated. As detailed in Section 4, the same restrictions would probably have applied to the Rajah, who may have only been allowed to pen a copy of the Qur'an (which would have been the first in South Africa) but which has gone missing), on the pretext of it being a gift to Governor Willem Adriaan for his hospitality.

What may cause some confusion are the references to 'Malays' and 'Maleits' (Malay language) in this article which focuses on Indonesia. Early authors have identified Muslims at the Cape who came from Indonesia, as 'Malay'. ${ }^{71}$ This was understandable given that East Malaysia and Indonesia both formed part of the Malay-Indonesian Archipelago (which was called East Indies) during the period of Dutch occupation. It is in this context that the term 'Malay' is also used in Company records and the travelogue by the British author, Lady Duff Gordon, referred in this article. However, the focus in this article is on Indonesia and not modern Malaysia because both Shaykh Yusuf and the Rajah of Tambora hailed from Indonesia. The Malay language spoken at the Cape at the time may also have been common to these now separate countries (Indonesia and Malaysia). This also explains why Afrikaans, a form of creolised Dutch $^{72}$ and one of eleven official languages in South Africa, contains many words common to both the Indonesian and Malaysian languages.

For the sake of cross-referencing and convenience, I have numbered all quotations from Company correspondence (Letters and Resolutions) incorporated into this article, pertaining to the families of Shaykh Yusuf and the Rajah and which were received $(1695-1708)^{73}$ at

71 See, for example I.D. Du Plessis, The Cape Malays: History, Religion, Traditions, Folk Tales: the Malay Quarter, 3d edition (Cape Town: A. A. Balkema, 1972).

72 By the late 18th century, a local Dutch-based creole language had developed at the Cape, as a result of interaction of people who spoke a variety of languages but who had to communicate in Dutch. This became known as Afrikaans and it was eventually to become dominant in the homes and streets of the Cape and adopted widely in South Africa. See "Legacy of Slavery: Heritage of Slavery", Iriko Museums of South Africa, https://slavery.iziko.org.za/legacyofslavery, accessed 31 Mar 2020.

73 Unless otherwise indicated, all quotations from the letters received from Batavia were extracted from the full text of H.C.V. Leibbrandt, Precis of the Archives of the Cape of Good Hope: Letters received, 1695-1708 (Cape Town: W.A. Richards \& Sons, 1896), http://archive.org/details/precisofarchives00cape_3, accessed 31 Mar 2020. 
the Cape from the Company headquarters in Batavia and which were despatched (1696-1708) $)^{74}$ by the Dutch government at the Cape to Batavia, in order of their respective dates of receipt and despatch. The article also refers to important Resolutions and correspondence dated after these periods. Shaykh Yusuf entourage at the Cape included his four wives, a dozen of their children and 14 friends of whom a few were imams and some were also his relations. The Rajah had five children, all born during or between his two periods of exile. The dramatis personae of this mystery are therefore many and also variously named. The persons referred to, their relationships to each other, as well as the several names by which many of them were referred to in the various sources, are detailed in Sections 3, 4 and 6. The spelling variations in the names of persons and titles in Company correspondence were mainly due to the fact that "there were no regular spelling conventions to adhere to during the VOC period". ${ }^{75}$

\section{The Family of Shaykh Yusuf in Indonesian and South African Historical Contexts}

Shaykh Yusuf's Indonesian name was Abidin Tadia Tjoessoep. He later became known as Shaykh Yusuf of Makassar. Sources dealing with Shaykh Yusuf variously add the toponym 'Makassar' or 'Macassar' to his name to respectively reflect his place of birth in Indonesia or his place of death in Cape Town, South Africa. He is also referred to in several sources by different variants of his name. For example, the title 'Shaykh Yusuf al-Taj al-Khalwatt-al-Naqasar' highlights both his acquired knowledge of Sufism and the status to teach it to others. In Dutch Company records and sources the title 'Shaykh' is variously spelled 'Sheik', 'Shech', 'Sleg' or 'sjeich'; the name 'Yusuf' as 'Joseph', 'Joesoef' or 'Jussuf'; and he is also variously referred to by several aliases, such as, Tuanse (Maccassarian priest) or 'moorish pope'. In this article, he is, for the sake of convenience,

${ }^{74}$ Unless otherwise indicated, all quotations from the letters despatched from the Cape were extracted from the Full text of "Precis of the Archives of the Cape of Good Hope: Letters despatched, 1696-1708”, H.C.V. Leibbrandt, Precis of the Archives of the Cape of Good Hope: Letters despatched, 1696-1708 (Cape Town: W. A. Richards \& sons, 1896), http://archive.org/details/precisofarchives00cape_1, accessed 31 Mar 2020.

75 See Liebenberg, Introduction to the Resolutions of Cape of Good Hope, p. 6. 
referred to as 'Shaykh Yusuf' or 'Shaykh Yusuf of Makassar'. Zytie (or Siety/Ziety) Sara Marouff has, besides 'Care Sale', also been attributed the following aliases: 'Care Sangie' and 'Kare Mami'.

The spelling of the names of Shaykh Yusuf's wives and children, as provided in the list dated 30 October 1699 compiled by the VOC in Batavia, may not necessarily coincide with the Indonesian spelling, and some names also may have fallen into disuse in Indonesia. Given that Shaykh Yusuf also had family from Sri Lanka of Sinhalese descent, some of these names could also have originated from there. It is common for Muslims to prefix their sons' names with the Prophet Muhammad's name and this was also the case with the names of some of Shaykh Yusuf's sons. 'Siety' is an honorary title for female Muslims and is adopted from the title given to women during the period of Muhammad's prophethood, for example, Muhammad's wives, Siti Khadijah and Siti Aisyah and his mother Siti Aminah. According to Dangor ${ }^{76}$, "'Siety' is probably a corruption of the Arabic 'Sayyidati' meaning my lady or simply 'Sayyida' meaning lady or madam". It is uncertain what the title 'Kare' means. According to Dangor ${ }^{77}$ Kare, "(a)lternatively spelt Care, is a Macassarese noble title applicable to both sexes." It could also refer to 'Karo', an ethnic group included in the term 'Batak' (Sumatera Utara) people. ${ }^{78}$ Apart from the fact that the mentioned persons are referred to by various names and aliases, the combining of their Indonesian names with Arabic names and their subsequent 'Dutchification' has created much confusion and has often made it difficult to identify them with accuracy. Names are also a mixture of Dutch and Makassarese spelling.

Shaykh Yusuf was born in the kingdom of Gowa (or Goa), Makassar, which is located on the Indonesian island of Sulawesi (earlier

${ }^{76}$ Dangor, Shaykh Yusuf of Makassar, p. 19.

77 Ibid., p. 13.

78 The term Batak is one of convenience, likely coined during precolonial times by indigenous outsiders (e.g., the Malay) and later adopted by Europeans. The groups embraced by the term... (which include)... the Karo... have to a limited degree adopted it as a self-designation. See "Batak: people", Encyclopedia Britannica, https:// www.britannica.com/topic/Batak, accessed 31 Mar 2020. 
Celebes), on 3 July 1626 or $1627 .^{79}$ According to a summary by Dangor, while there is uncertainty as to who exactly Shaykh Yusuf's father was, his mother, who was apparently related to the kings of Goa, is reported to have married the Indonesian King of Goa (unspecified by name but whom Dangor also implies is the variously named Sultan Ala al-Din Mangarangi Daeng Maurabija who ruled from 1593 to 1639) whilst she was separated from his father and still pregnant with him. The King of Goa subsequently adopted him. ${ }^{80}$ Dangor's summary highlights that Shaykh Yusuf was therefore not the natural son of the King and that the Shaykh's mother entered into marriage whilst pregnant with him. This goes contrary to Islamic law (Shari'a). According to Jappie, ${ }^{81}$ Abu Hamid appears to proffer a different view, namely, that the Shaykh's mother only married the King some 40 days after his birth. While Abu Hamid's view would address such a deviation, the Shari'a requires that a Muslim woman must observe a prescribed period of waiting (idda) after either separation from or death of her husband during which time she may not enter into marriage with another man. One of the practical reasons for doing so is precisely to ensure that the identity of a child's father would be known to him or her. ${ }^{82}$ While Islamic law permits adoption (kafala), the relationship between the child and its adoptive guardian is regulated by very specific rules which are quite different from secular law. For example, it does not consider such a child to be a blood relative of the guardian and encourages the retention of a biological family name (surname) ${ }^{83} \mathrm{~A}$ plausible explanation in justification of such deviation

79 There are sources that indicate his birth to have occurred in either year. There is a discrepancy in some sources about whether Shaykh Yusuf was born in 1626 or 1627. For example, N. Lubis deems him to have been born in 1626 while A. Azra indicates that he was born in 1627. Lubis, "Min A'lāmi Indūnīsīya"; Azra, The Origins of Islamic Reformism in Southeast Asia, p. 87. See Dangor, Shaykh Yusuf of Makassar, p. 5.

80 Ibid., pp. 5-6.

81 Jappie provides no further citation for Abu Hamid. See Jappie, "Between Makassars", p. 32.

82 See Najma Moosa, "The Dissolution of a Muslim Marriage by Divorce”, in The Law of Divorce and Dissolution of Life Partnerships in South Africa, ed. by Jacqueline Heaton (Cape Town: Juta \& Co Ltd, 2014), pp. 322-4.

${ }^{83}$ For details see Usang M. Assim and Julia Sloth-Nielsen, "Islamic Kafalah as an Alternative Care Option for Children Deprived of a Family Environment", African 
from Islamic law may be the fact that, at the time of the Shaykh's birth, Islam was still a fledgling religion in Indonesia and had only become the religion of the Makassar kingdom in $1603,{ }^{84}$ some 23 or 24 years before his birth. Nonetheless, Shaykh Yusuf was fortunate to have a mother that was of royal stock and to be 'born' into a royal family which both raised him and encouraged him to acquire an Islamic education, which included the memorisation of the entire Qur'an (hafiz) from a young age. ${ }^{85}$ Dangor highlights that Shaykh Yusuf may also have been of royal stock because his mother was related to the kings of Goa. ${ }^{86}$ As will be detailed in Section 7, this would explain his familial connection to Radja Goa (Abd al-Jalil), the 19th King of Goa, and the latter's keen interest (as also indicated in Company correspondence) in securing the return of Shaykh Yusuf and his entourage from the Cape, and among whom the Shaykh and the King may also have had other family members, as follows: "(t)he king who continued to request the return of Shaykh Yusuf was his maternal uncle (Sultan) Abd al-Djalil, who ruled 1677-1709". ${ }^{87}$ The fact that after his death in 1709, Abd al-Jalil was buried next to a second grave of Shaykh Yusuf located in Gowa, Lakiung in Ujung Pandang (Makassar) highlights this familial connection. ${ }^{88}$

As will be detailed later in this Section, the Shaykh eventually also married several women [including two daughters of his patron the Sultan of Bantam (also known as Abd al-Fattah or Ageng Tirtayasa, ruled. 1651-1682 or 1683$)^{89}$ belonging to both royal and religious families. His fifth and head wife at the Cape, Care Contoe, was one of Sultan Ageng's two daughters. ${ }^{90}$ From the age of 17 or 18 , the Shaykh's quest for further

Human Rights Law Journal (AHRLJ), vol. 14, no. 2 (2014), pp. 326-7; 329-31.

${ }^{84}$ Dangor, Shaykh Yusuf of Makassar, p. 5.

85 See abstract summary in.Lubis, "Min A 'lāmi Indūnīsīya".

86 Dangor, Shaykh Yusuf of Makassar, p. 6.

87 See Van Rensburg, “The Enigma of Shaykh Yusuf's Place of Burial”, p. 84. See also Jean Gelman Taylor, Indonesia: Peoples and Histories (New Haven \& London: Yale University Press, 2003), p. 170.

88 Jappie, "Between Makassars", p. 105.

89 Azra says '1683' and Taylor says '1682'. Azra, The Origins of Islamic Reformism in Southeast Asia, p. 95; Taylor, Indonesia, p. 124.

90 See text to footnote 133 for details of his marriages to the two daughters of Sultan Ageng. 
knowedge resulted in his travelling, ${ }^{91}$ from 1644, and acquiring schooling in the disciplines of Islamic law (Shari'a), including the jurisprudence of the Shafi'i school of law to which he belonged, and training in various Sufi orders (tariqas). ${ }^{92}$ As a consequence, Shaykh Yusuf became a reputed Sufi saint of many orders, ${ }^{93}$ a Muslim cleric (alim), scholar of note and author of several books (as detailed in Section 2). He is also deemed to have performed the pilgrimage (bajj) ${ }^{94}$ to Mecca in 1654 at the unusually early age of 27 or $28 .{ }^{95}$ This was some 157 years before the first Muslim would do so from the Cape. ${ }^{96}$ Although the dates that he returned from studies and travels (in 1664 after 20 years or in 1672 after 28 years) and the place to which he first returned (Bantam or Banten in Java or Gowa in Makassar) are disputed by scholars, 1668 (as suggested by a $10^{\text {th }}$ generation descendant of Shaykh Yusuf, Ms Sahib, who is referred to several times in this article) appears to be a more plausible date, and Bantam a more logical return destination, because the VOC had taken over Macassar in 1667. ${ }^{97}$ It would not have made sense for him to return to him hometown (Gowa) given that the Dutch were in control there.

Shaykh Yusuf led a guerrilla struggle against the Company in

91 He travelled widely in Southeast Asia, South Asia and the Middle East. At first he travelled to places like Bantam and Aceh in his own country (East Indies). In 1649 he departed from there for Arabia via Gugarat in India. He travelled to Yemen, Mecca, Medina, Jeddah, Damascus (Syria) and possibly, Istanbul, in Turkey although the latter visit cannot be confirmed. For detail see Dangor, Shaykh Yusuf of Makassar, pp. 7-13.

92 Ibid., p. 7.

93 Lubis, "Min A'lāmi Indūnīsīya", p. 149.

${ }^{94}$ Haj, the greater Muslim pilgrimage to the holy city of Mecca, is one of the five pillars of Islam. The Arabic term 'haji' is an honorific title bestowed on a male person who has travelled to Mecca and successfully completed this pilgrimage. The term 'hajah' is the female version of 'haji'.

95 For detail see Dangor, Shaykh Yusuf of Makassar, pp. 7-10.

96 The first pilgrims from South Africa only did so in 1811 (Imam Abdulgamiet or Abd al-Hamid) or between 1834 and 1837 (Hajji Gassonnodien alias Carel Pilgrim) during the second period of British occupation. See Mogamat Hoosain Ebrahim, "The Transformation in the Management and Traditions of Hajj at the Cape", PhD. Dissertation (Durban: University of KwaZulu-Natal, 2007), pp. 25-6.

97 Ibid., p. 14. 
Bantem. ${ }^{98}$ On 14 December $1683^{99}$ the Dutch captured him in Bantam for his 'anti-Netherlands activities' and brought him to Batavia on Java (now Jakarta), the Company's then headquarters in the East Indies. According to Greyling: "The authorities in Batavia sent a boat to bring Schech Yusuf, his wives and children as well as his following of twelve Muslim priests (tempelpapen) to Batavia, where they arrived on 14th March 1684". ${ }^{100}$ According to Van Rensburg when: "Yusuf finally surrendered in 1684 together with twenty-four men (mainly priests) and four women...An entry dated 19 February 1684 notes that Yusuf's followers returned to Celebes (which later became Sulawesi) on the ship 'De Merwe"'. ${ }^{101}$ Yet, the following several sources, including Van Rensburg, also all clearly indicate that twelve imams (presumably the same twelve mentioned by Greyling) followed him from Batavia to Ceylon. As detailed below, these twelve imams are then inferred by Indonesian scholar Azra ${ }^{102}$ (and others) to have accompanied him to the Cape where they are deemed to have assisted the Shaykh with proselytising activities, which, according to Azra, also kept him so busy that he was unable to pen any further treatises. Moreover, for the reasons already alluded to in Section 2, it is contended that Azra's ${ }^{103}$ following account was based more on his imagination than fact:

...the Dutch not only prohibited Muslims from openly holding religious services but, worse still, ordered the Christianisation of all Muslim slaves in the Cape...The Dutch evangelist scholar Zwemer even regrets the failure of Petrus Kalden, first minister of the Old Dutch Church at Cape Town, to convert al-Maqassari to Christianity, despite the fact that the latter lived on land belonging to the minister. Zwemer bluntly points out

98 Meg Samuelson, “Orienting the Cape: A 'white' Woman Writing Islam in South Africa", Social Dynamics, vol. 37, no. 3 (2011), p. 364.

99 Azra, The Origins of Islamic Reformism in Southeast Asia, p. 98.

100 Greyling, "Schech Yusuf, the Founder of Islam in South Africa", p. 15. Greyling uses De Haan's Priangan at page 283 as his reference. Frederik de Haan, Priangan: De Preanger-Regentschappen onder het Nederlandsch Bestuur tot 1811, vol. 3 (Batavia: Bataviaasch Genootschap van Kunsten en Wetenschappen, 1912), p. 283. Dangor, Shaykh Yusuf of Makassar, p. 39. Dangor also confirms that there were 12 priests (imams).

101 Van Rensburg, "The Enigma of Shaykh Yusuf's Place of Burial”, p. 74.

102 Azra, The Origins of Islamic Reformism in Southeast Asia, p. 101.

103 Ibid., p. 102. 
that a great opportunity was lost by Kalden.

According to Van Rensburg, ${ }^{104}$ who uses Indonesian Abu Hamid ${ }^{105}$ as his reference:

On 13 (some sources say 12) September 1684, Shaykh Yusuf, now aged 58 , was sent by the ship 'Coevorden' to the Castle in Colombo, Ceylon... Two wives and two maids, twelve holy men and sons and daughters, as well as slaves and some of his pupils accompanied him.

Azra writes that that he was exiled to Sri Lanka "(i)n September $1684 \ldots$ together with two wives, several children, 12 disciples and a number of maids...Furthermore, al-Maqassari (Shaykh Yusuf) appears to have left some descendants in Srilanka (Ceylon)..." ${ }^{106}$ The ninth and tenth generation descendants of Shaykh Yusuf, born from his marriages and offspring whilst he was in exile in Sri Lanka and the Cape, paid an historic visit to Johannesburg, a city in Gauteng province, South Africa, on 26 April $2017 . .^{107}$

104 Van Rensburg, “The Enigma of Shaykh Yusuf's Place of Burial”, p. 74.

105 Abu Hamid, Syekh Yusuf Makassar: Seorang Ulama, Sufi dan Pejuang, (Jakarta: Yayasan Obor Indonesia, 1994), pp. 108-9.

106 Azra, The Origins of Islamic Reformism in Southeast Asia, p. 98.

107 Ebrahim Moosa, "Descendants of Sheikh Yusuf visit Johannesburg", Radio Islam (27 Apr 2017), https://www.radioislam.org.za/a/descendants-of-sheikhyusuf-visit-johannesburg/, accessed 31 Mar 2020. The descendants of Shaykh Yusuf visited South Africa for the first time in April 2017. They paid a visit to Cape Town and followed this with a visit to Johannesburg. This historical visit was reported by a Gauteng correspondent in a June 2017 edition of a Cape based Muslim newspaper as follows: Gauteng correspondent, "Descendants of Shaikh Yusuf of Makassar on goodwill visit to SA", Muslim Views (23 Jun 2017). The report in Muslim Views indicates that the delegation also paid a goodwill visit to Cape Town during their stay and that Ms Muzdalifah Sahib was also in attendance with her father and sister at the historic Johanneburg meeting. As indicated previously, Ms Sahib is a tenth generation descendant although the reports in Muslim Views and on Radio Islam news refer only to eighth and ninth generation descendants of Shaykh Yusuf that were in attendance. This is incorrect because there were no eight generation descendants in attandance. This was confirmed in a Personal communication (20 April 2020) with Ms Takudaeng (aka Keke) Parawansa, another $10^{\text {th }}$ generation descendant, who was also in attendance. She indicated that the delegation, comprised of seven family members as follows: Ms Keke Parawansa $\left(10^{\text {th }}\right.$ generation); her father Drs. Mappaturung Parawansa ( $9^{\text {th }}$ generation); her uncle Prof. Dr. Paturungi Parawansa ( $9^{\text {th }}$ generation); her cousin Dian $\left(10^{\text {th }}\right.$ generation $)$ (the daughter 
Dangor (citing Azra), ${ }^{108}$ reiterates that when he was exiled from Batavia to Ceylon (Sri Lanka) the Shaykh was accompanied by "two wives, children, twelve disciples and several servants". In so doing, the errorneous belief that his focus at the Cape was on prosethelysation activities continued to be upheld.

After spending almost a decade in Ceylon, also a then VOC trade post, it appeared that the Dutch deemed him to still be too close to Indonesia for 'political' comfort. In terms of a Company Resolution (dated 7 July 1693) the Dutch government at Batavia decided to transfer Shaykh Yusuf to the Cape. ${ }^{109}$ As indicated, on 23 January 1694 he was transferred from Ceylon to the Cape of Good Hope located further away at the southernmost tip of the African continent. He arrived at the Cape at the age of $67 / 68$, with what appeared to be an even larger entourage of 49, on board the Dutch ship, 'Voetboog', on $2^{110}$ or $16^{111}$ April 1694. ${ }^{12}$ Although some sources claim the year to be either 1693 or 1694, it appears from Company sources that the Resolution was dated 1693 but that he had both departed from Ceylon, and arrived at the Cape, in 1694. As indicated in Section 2, he died at the Cape on 22/23 May

of Prof Paturungi); Ms Muzdalifah Sahib (10 ${ }^{\text {th }}$ generation); her father (Sheikh K.H Sahib Sultan ( $9^{\text {th }}$ generation $\left.)\right)$ and her sister Raodah $\left(10^{\text {th }}\right.$ generation $)$. The delegation had arrived at the Cape on 15 April 2017 to attend the Kramat Festival held annually in Macassar, Faure in honour of Shaykh Yusuf. The family lived in Faure for ten days to be near to the shrine of Shaykh Yusuf. Ms Parawansa's father and late mother are cousins married to each other. Both are $9^{\text {th }}$ generation descendants of Shaykh Yusuf descended through the same roots, that is, Shaykh Yusuf's fifth (and head) wife at the Cape, Cara Contoe (also known as Khatijah or Sharifah Fatima). Care Contoe was one of two daughters of the Sultan of Bantam, Ageng Tirtayasa, that the Shaykh was married to. Ms Muzdalifah Sahib and her family's links to the Shaykh Yusuf can be traced back to his ninth wife, Naima (alias Afifah), who was from Ceylon. She was the daughter of Abd Allah Sarnadib (a former name of Ceylon). Naima (Afifah) also accompanied Shaykh Yusuf to the Cape.

108 Dangor, Shaykh Yusuf of Makassar, p. 39.

109 Jappie, "Between Makassars", p. 49.

110 Ibid., p. 42.

111 Van Rensburg, "The Enigma of Shaykh Yusuf's Place of Burial”, p. 84. Note 44 has taken the trouble to point out that sources referring to the day of his arrival at the Cape varied.

112 Dangor, Shaykh Yusuf of Makassar, pp. 40-2. 
1699 at the age of $73 / 74$. Until a year prior to his death, the Shaykh was denied permission to return to Indonesia despite his advanced age (72). Shaykh Yusuf's exile at the Cape was a mere five years, but if we add the one year that he was imprisoned in Batavia, and the nine years spent in exile in Ceylon, his exile comes to a total of almost 16 years. If we add his prior 20-year period in search of knowledge abroad, then he spent nearly half his life in some or other form of 'exile'. In comparison to his exceptional life up to this point, Shaykh Yusuf's short banishment to the Cape appears to have been uneventful.

In a letter despatched from the Cape on 1 July 1699, ${ }^{113}$ some six weeks after the Shaykh's death, the Dutch government at the Cape informed its counterpart in Batavia of his death and requested to be relieved of his entourage. Batavia responded by sending a letter (which included an extract from a Resolution) to the Cape dated 30 October $1699^{114}$ in which it granted permission for their return to Indonesia.

113 Leibbrandt, Precis of the Archives of the Cape of Good Hope: Letters Despatched, 1696-1708, p. 125. Letter (Number Two) Despatched from the Cape, 1 July 1699, "No. 56, p. 473. Ships affairs. . On the 23rd May this year (1699) the Mohammedan priest, Sheik Joseph, who had by your orders been sent hither in 1664 with 49 followers in the flute 'Voetboog,' from Ceylon, departed this life. Until the end of August, 1698, they, and others of their kind, have cost this Government in pay and maintenance... a heavy burden indeed on our revenue. Besides, these Mohammedans, by multiplying, are more and more increasing in numbers. However, as Joseph is now dead, we beg you to find a proper method by which we may be released from his adherents and their heavy expense, and also that we may in future be exempted from such people...".

114 Leibbrandt, Precis of the Archives of the Cape of Good Hope: Letters Received, 1695-1708, p. 215. Letter (Number Two) Received at the Cape, 30 October 1699, "No. 89, p. 449. Extract from the Resolutions of the Castle at Batavia, dated 30th October, 1699: 'Having considered the written request of Dayeeng Nisayo, the officers, and others among the chief Maccassar residents, that there may be ordered back from the Cape of Good Hope, the wives, children, friends, and slaves of the well known Maccassar Priest Sheik Joseph, who, as advised by the Governor and Council of the Cape, in their despatch dated 1st July, 1699, had died there on the 23rd May preceding, viz.: 2 wives named Cara Contoe (or Karakonto) and Cara Pane. 2 concubines named Monuma and Naima. 12 sons and daughters named Moehama Radja, Radeengh Boerne, Moehama Hay, Moehama Djalani, Roemalang, Jaha- math, Care Sangie, Siety Caeaty, Issa, Sanda, Sito Romia, and Siety Labieba. 14 male and female friends of the late Sheik, viz.: Pia, Boeleengh, Care Manangh, Abida, Amida, Biby, Isa, Sarie, Dayeengh Maniko, Casim, Kentol Taib, Ragoena, Aboebahar, Abdul Rahoef, Abdul Jaffan; likewise some slaves 
Although the Resolution records the names of his entourage upon his arrival (1694), it is dated after his demise in May 1699. The cause of much confusion is the fact that the list of names mentioned in the extract dated 30 October 1699 actually only lists the names of those who arrived at the Cape (in April 1694). As indicated below, their numbers had increased since then, which may account for the 60 that departed from the Cape and arrived back in Indonesia in 1704. Although there is an Annexure (1704) $)^{115}$ which lists the names of those who departed from the Cape, and which may therefore have detailed which of the remaining 49 members of his initial entourage actually left the Cape in 1704, this Annexure unfortunately appears not to be available locally.

Although the efforts of his royal relative, the Rajah of Goa (Abd al-Jalil), to secure his return, finally were successful, it was to take another four to five years after Shaykh Yusuf's death before the entourage eventually departed in 1704, bringing their total stay at the Cape to ten years. When the Shaykh was transferred to the Cape from Ceylon, the Company Resolution (dated 30 October 1699) indicates that he arrived there with an entourage of 49. However, the actual Company Resolution only lists 30 (of the 49) names of persons who accompanied Shaykh Yusuf to the Cape, as follows: "2 wives...2 concubines...12 sons and daughters...14 male and female friends...(and) some slaves whose numbers and names have not been given". According to the Resolution (30 October 1699), the names and status of the 30 persons that formed part of the Shaykh's entourage were as follows: his two wives, Cara Contoe (or Karakonto) and Cara Pane; his two concubines, Monuma and Naima; his twelve children, of whom five were daughters (Care Sangie;

whose number and names have not been given; it was decided for the present to recall hither the wives and daughters of the said Sheik Joseph, and as yet to leave there the sons and the so-called male and female friends of the late priest. Should, however, any of the wives and daughters have sons not older than five or six years, such, and others that may be younger, but no sons older than that, are allowed to return hither. It was further decided to keep tbe slaves there and have them valued for the Company, that the proceeds might be applied to the reduction of what had been expended for the maintenance of the said priest and his retinue; and further to diminish the establishment in proportion to the number left; and what they might comfortably be maintained with. Compared with the original, and found to agree with it on the 20th November, 1699. J. Uldrix, 1st Clerk."

115 See footnote 284 for reference to this Annexure. 
Siety Caeaty; Sanda; Sito Romia and Siety Labieba) and seven were sons (Moehama Radja; Radeengh Boerne; Moehama Hay; Moehama Djalani; Roemalang; Jahamath; and Issa); and his fourteen friends, of whom five were females (Pia; Abida; Amida; Biby and Sarie) and nine were males (Boeleengh; Care Manangh; Isa; Dayeengh Maniko; Casim; Kentol Taib; Ragoena; Aboebahar; Abdul Rahoef and Abdul Jaffan). ${ }^{116}$ Although we can gauge, albeit with some difficulty, the sex of Shaykh Yusuf's children from their names, their ages are not given.

Although this is not evident from the above list of 30, Dangor ${ }^{117}$ citing Greyling's ${ }^{118}$ thesis as his source, indicates that besides the 14 male and female friends, an additional 12 imams also accompanied the entourage, bringing his total number to 42 . Dangor goes on to explain that in order to bring the number to 49 , the rest (7) would have been slaves as follows:

...of the total of 49 people who made up Yusuf's retinue when he arrived at the Cape 16 were members of his family ( 2 wives, 2 slavegirls, 12 children), 12 imams, 14 friends with their families. The rest (7) were his servants. ${ }^{119}$

I contend that, based on the following facts, Dangor's estimate (totalling 49) may not be correct. The Company Resolution (30 October

116 The distinction between the female and male names were confirmed through personal communication with Indonesian Prof Euis Nurlaelawati, 25 March 2020. As indicated in Section 2, Care (also spelt Kare) is used in both feminine and masculine contexts. Some names (like Abdul Rauf, Kasim, Sari and Amida) are still in use in Indonesia. 'Pia' is more than likely a nickname and the shortened form of a longer name.

117 Dangor, Shaykh Yusuf of Makassar, p. 42.

118 Christeman Joel Andries Greyling, "Die Invloed van Strominge in die Islam op die Jesusbeskouing van die Suid-Afrikaanse Moslems", PhD. Dissertation (Stellenbosch: Stellenbosch University, 1976), p. 12. Although I was unable to locate a copy of Greyling's thesis to verify which source he may have used, I was able to clarify the matter from Greyling's 1980 article on Shaykh Yusuf.

119 See Dangor, Shaykh Yusuf of Makassar, (Durban: Iqra Publishers, 1994), p. 39. Its note 48 located at end of Dangor's chapter on p. 52. The same information is contained in his thesis at page 42 (Suleman Essop Dangor, "A Critical Biography of Shaykh Yusuf", Master Thesis (Durban, South Africa: University of KwaZulu-Natal, 1981). Its note 48 and in the latest edition of his book page 49 at its note 88 (Suleman E. Dangor, Shaykh Yusuf of Makassar, 3rd edition (Durban: Digniti, 2019). 
1699) ${ }^{120}$ clearly only refer to ' 14 male and female friends' and 'so-called male and female friends'. A Letter received at the Cape (dated 23 November 1699) $)^{121}$ also refers to the 'so-called friends' of Shaykh Yusuf. Neither the Resolution or the Letter makes any mention of 'imams', let alone twelve of them. We can therefore only infer from Van Rensburg and Dangor (referred to above) that some of these male 'friends' may have been imams (or followers) of the Shaykh that accompanied him to the Cape from Ceylon. However, according to Greyling, ${ }^{122}$ as many as 12 of these 14 friends who accompanied Shaykh Yusuf to the Cape were indeed imams: "His fourteen friends included "12 santrijs off tempelpapen"', which he also translates as 'Twelve Muslim officials'. ${ }^{123}$ Given that this would imply that only two of the 14 friends were women, it is contended that Greyling's assessment is incorrect and that the reverse may have been true, namely, that of the 14 friends (of mixed gender)

120 See footnote 114 .

${ }^{121}$ Leibbrandt, Precis of the Archives of the Cape of Good Hope: Letters Received, 1695-1708, p. 222. Letter (Number Three (i)) Received at the Cape, 23 November 1699. "The death of the Moorish priest Sheik Joseph, has relieved the Company of a great burden, both as regards the requests of our Mohamedan allies (to which we were continually exposed) that he might be ordered back, and the costs necessary for his maintenance, which including what has been spent for some years on the Macassar grandees have reached the big sum of (26,221 guilders) How you are henceforth to act with this item, and others required for the said Macassars and other convicts, you will gather from the annexed memorandum of the general bookkeeper, dated 18th September last The return fleet this year will he under the command of the ordinary Councillor of India, Wouter Yalckenier, who will likewise be Commissioner for the Cape. The Vice-Admiral will be the Councillor Extraordinary Wybrand Lycochton, and the Rear-Admiral, Thomas van Son. At the request of his friends we have allowed the wives and daughters of the late Sheik Joseph to return hither, but the sons and so-called friends of the said priest are to remain there and be moderately entertained according to their numbers. Their slaves are to be appraised and taken over for the Company. The amount to he employed in reduction of the expenses incurred in their maintenance. Everything else must remain in accordance with our Resolution of 30th October, 1698". Letter (Number Three (ii) Received at the Cape, 23 November 1699. Ibid., p. 232. "No. 123, p. 649. No. 8. Extract from the resolution of the Batavia Government, dated 30th October last, regarding the friends and domestics of the late Sheik Joseph."

122 Greyling, "Schech Yusuf, the Founder of Islam in South Africa", pp. 15-6. Greyling uses De Haan's Priangan at page 283 as his reference. Haan, Priangan: De Preanger-Regentschappen onder het Nederlandsch Bestuur tot 1811, vol. 3, p. 283

123 Ibid., p. 21. 
only two may have been imams (who are by definition male) on the basis of the following information. From the Company list of 14 names, at least five (therefore more than two) were female as is evident from their names: 'Pia'; 'Abida', 'Amida', 'Biby', and 'Sarie'. The Company Letters ${ }^{124}$ only indicate that 'one woman' and 'her two children' remained behind when the Shaykh's entourage left the Cape. However, Dangor appears to believe otherwise. Without identifying them as imams, he relies on Jeffrey as a source to indicate that, besides Zytie (who, as will be detailed below and in Section 5, Dangor also believes was the Shaykh's daughter who remained behind) two other members also elected to remain behind at the Cape when the rest returned in 1704:

Two other-members of Yusuf's retinue of forty-nine requested the Cape authorities for permission to stay at the Cape and, therefore, were not sent back to the East Indies. ${ }^{125}$

Another scholar, Bradlow, ${ }^{126}$ cites a different reference where Jeffreys refers to the burial place of 'one of those (followers) who remained behind'. That only two imams that were still alive then may have opted to remain behind, would further corroborate my view, and other views, like that of Tayob (detailed in Section 2), that the Shaykh and his imam follower/friends (who now appear not to have totalled 12) may not have been involved in much, if any, proselytising acitivites at the Cape, not only because of their decreased number, but also because of the policies which banned such activities with severe penalties (including the death sentence) for infringement.

Davids, relying on Jeffreys, continues the misperception: "At Zandvliet, Tjoessoep's settlement soon became a sanctuary for fugitive slaves... Only two of his followers and his daughter remained behind". ${ }^{127}$

124 See footnotes 285 and 284.

125 M.K. Jeffreys, "The Malay Tombs of the Holy Circle - VI: The Kramat at Zandvliet, Faure, Part 2: Sheik Joseph at the Cape", The Cape Naturalist, vol. 1, no. 6 (1939), p. 197; Dangor, Shaykh Yusuf of Makassar, 3rd edition, p. 49.

126 Muhammad 'Adil Bradlow, "Imperialism, State Formation and the Establishment of a Muslim Community at the Cape of Good Hope, 1770-1840: A Study in Urban Resistance", Master Thesis (Cape Town: University of Cape Town, 1988), p. 123.

${ }^{127}$ Davids, The Mosques of Bo-Kaap, pp. 39; 191. 
As indicated in Section 2, given that only 30 names are actually accounted for, would imply that the rest (19) were slaves; but such a number would be disproportionate when compared to the number of names (30) listed. It is therefore contended that while some were indeed slaves, the rest were probably unnamed children belonging to the members of the entourage in general and not necessarily limited to those belonging to Shaykh Yusuf's family. This is corroborated by the Company Letter indicating that 'they were all intermarried'128 and the Company Resolution (30 October 1699) (29 $^{129}$ in terms of which only the Shaykh's sons and grandsons below the age of six were initially permitted to return to Indonesia. The names of Shaykh Yusuf's grandsons and his granddaughters are not included in the list of 30 names referred to above but definitely formed part of the entourage. Although some of his sons may also have been below the age of six, their names would have been recorded in the list. The Company had initially imposed stringent and complicated rules as to who would be allowed to return to Indonesia. Only the Shaykh's widows and daughters were able to return but not his older sons or male and female friends and slaves. However, the Shaykh's sons and grandsons under the age of six years were allowed to leave. Eventually, by the time they were to depart in 1704, Company records indicate that only 'one woman' and 'two of children' opted to remain behind and the Batavian authorities left it to the discretion of the authorities at the Cape to allow those who wanted to, to stay as well. This could therefore have included some (possibly two) imams as detailed above. Dangor ${ }^{130}$ also highlights that some of the Shaykh's friends may have also died at the Cape: "Four of Shaykh Yusuf's followers who accompanied him in his exile in 1694 were also buried near him."

Although Dangor ${ }^{131}$ is of the opinion that only the Shaykh's immediate family, excluding his older sons and grandsons, returned to Indonesia, Company correspondence indicates otherwise. As indicated in Section 2, unlike the case of Mandela and other political exiles in

128 See footnotes 245 and 246 for the contents of this Letter and reference to its Annexure.

129 See footnote 114 above.

130 Dangor, Shaykh Yusuf of Makassar, $3^{\text {rd }}$ edition, p. 56. See also footnote 30.

131 Ibid., pp. 48-9. 
South Africa who were held in isolation without their families, Shaykh Yusuf and other exiles like him were accorded special privileges which allowed their families, friends and helpers to accompany them to the Cape. This would explain why, on the demise of her husband in 1699, his widow, Care Contoe, given her former role as head wife in a polygynous marriage (with two to four women), and intermarriage ${ }^{132}$ between their families and that of their friends, had donned the hat of matriarch and, boldly and persistently, petitioned for the repatriation of not only her entire family (regardless of their gender and ages) but of the entourage as a collective. We can glean the importance of this familial link from the VOC correspondence which highlights Care Contoe's resolve (as mother, stepmother, aunt or sister-in-law) that they would either leave as a unit or stay as a unit, but that she was not prepared to divide the entourage. For example, among the entourage was Care Contoe's own two children Moehama Hay (aka 'Muhammad Abd Allah' or 'Muh Sa'ad') and Labieba (aka 'Habiba') and Moehama Radja (aka 'Muhammad Jalal al-Din' or 'Muhammad Rajah') who was the son of her deceased sister. As indicated in Section 3, Shaykh Yusuf was married to two daughters of Sultan Ageng. He married Cara Contoe (wife number 5) only after her sister Sharifa Habiba (wife number 4) had died. Care Contoe was therefore both stepmother and aunt to Moehama Radja. ${ }^{133}$

She may also have been under the advisement of the imams, who formed part of the entourage, to adopt such a position. After four years of correspondence ${ }^{134}$ between the Government at the Cape and Batavia, by no less than slow 'sea' mail, the Batavian government finally capitulated

\footnotetext{
132 This will be detailed in Section 6.

133 Dangor, Shaykh Yusuf of Makassar, $3^{\text {rd }}$ edition, pp. 15-6; 86. See footnote 90.

134 This can be gleaned from the uncharacteristic four-year volley of letters, to and from, between Batavia and the Cape as follows: Letters Received at the Cape - Number Two (30 October 1699) (see footnote 114); Three (23 November 1699) (see footnote 121); Four (28 January 1701) (see footnote 248); Five (30 November 1702) (see footnote 249) and Six (1 December 1703) (see footnote 250) and Letters Despatched from the Cape - Number Three (26 March 1700) (see footnotes 245 and 246); Number Four (29 May 1701) (see footnote 252); Letter Five (18 May 1703) (see footnote 253); Letter Six (14 June 1704) (see footnote 327); Letter Seven (2 October 1704) (see footnote 284) and Letter Eight (6 April 1705) see footnote 287.
} 
and broke the deadlock by allowing the entourage to return as a unit, except, of course, for those who chose not to return. Unfortunately, Care Contoe's Annexed petition (dated 26 March 1700) which will be referred to in more detail in Section 6 and which could have shed more light on the relationship between members of the entourage, and, as indicated above, the Annexed list (referred to in a Letter dated 2 October 1704) which would have identified the members of the entourage who had in fact returned to Indonesia, and which were both despatched from the Cape to Batavia, are not available locally. However, it is contended that, based on the Company correspondence, and excluding the members who had succumbed at the Cape, the majority had returned to Indonesia. This view is in fact corroborated by Dangor, although he appears to contradict himself $\mathrm{f}^{135}$ in doing so, when he refers to both the subsequent marriage of a son of Shaykh Yusuf (which implies that he had to be above the age of six), and of his later death in Makassar, Indonesia, who had formed part of the entourage at the Cape.

As explained below, the entourage had increased in size at the Cape which would explain why it may have been necessary that they be split and depart separately from the Cape on two Company ships. An increase in numbers would also explain why the Company may initially have been motivated to want to keep their slaves behind in an attempt to recoup some of the costs of their upkeep. The Company's initial restriction pertaining to the Shaykh's older sons and male members of his entourage may also have been a security measure. Given his status, and high standing in his own community, the Company had deemed Shaykh Yusuf to pose a threat even after he died and were therefore initially loath to return his remains to Indonesia despite repeated requests to do so. ${ }^{136}$ The Company in Batavia may therefore possibly have anticipated an uprising by the masses once the entourage arrived back on home soil in 1704 since they were by then also expected to arrive together with the Shaykh's remains. This may in part also explain why, when the first part of the entourage arrived in Indonesia, they had to wait for the arrival of the rest of the party before being allowed to proceed to their

135 Dangor, Shaykh Yusuf of Makassar, $3^{\text {rd }}$ edition, pp. 19-20. See text to footnote 12 .

136 Van Rensburg, “The Enigma of Shaykh Yusuf's Place of Burial”, pp. 75-6. 
hometown (Macassar). ${ }^{137}$ Even then, it appears, his sons were forced to remain behind in Bantam for at least two years. ${ }^{138}$

Van Rensburg ${ }^{139}$ highlights that the two Company ships 'Liefde' (with 42 passengers on board) and 'Spiegel' (with 18 passengers on board) left the Cape on 5 October 1704. The 'Spiegel' was the first ship to arrive in Batavia on 10 December, whereas the 'Liefde' arrived a few days later on 15 December $1704 .{ }^{140}$ Given that the entourage arrived at the Cape in 1694 as 49 persons, of whom only 30 can be accounted for by name, but returned to Batavia ten years later (in 1704) as 60 persons, corroborates Company correspondence which highlights that its number had increased, and therefore so had the expenses of their upkeep. ${ }^{141}$ Given the length of their stay, status of isolation, and the policies banning proselytising activities (to be detailed in Section 7), it appears that the increase in number was due to natural causes and not have anything to do with proselytising activities that the Shaykh may have mistakenly been accused of. Thus, the fact that the Company Letter from the Cape (dated 1 July 1699) to the authorities in Batavia specifically mentioned that "... these Mohammedans, by multiplying, are more and more increasing in numbers", did not necessarily imply conversions to Islam but may have alluded to the increased expenses because of the increase in their number. According to Dangor's latest ${ }^{142}$ edition of his book on Shaykh Yusuf, the Shaykh was estimated, during his lifetime, to have entered into some nine marriages with six women in Indonesia, two in Arabia and one in Ceylon, and to have fathered some 14 children with them. Given that he arrived at the Cape with only two wives (or four, if we deem the concubines to be wives), he had by the time of his arrival been widowed a few times and two of his children had by then also died.

137 See Company Letters detailed in footnotes 285 and 287.

138 See M.K. Jeffreys, "The Malay Tombs of the Holy Circle - VI: The Kramat at Zandvliet, Faure, Part 2: Sheik Joseph at the Cape", The Cape Naturalist, vol. 1, no. 6 (1939), p. 197.

139 Van Rensburg, "The Enigma of Shaykh Yusuf's Place of Burial”, p. 78.

140 These dates are backed up by Company letters dated as follows: 2 October 1705 (see footnote 284); 6 April 1705 (see footnote 287) and 18 December 1704 (see footnote 285).

${ }^{141}$ See Company Letter detailed in footnote 113 above.

142 Dangor, Shaykh Yusuf of Makassar, $3^{\text {rd }}$ edition, pp. 9; 12-9. 
Of interest to the main argument of this article are the names of his daughters and who their mothers may have been. Shaykh Yusuf remained polygynously married to two wives, Care Contoe and Care Pane, until his death. In addition, the VOC Resolution (30 October 1699) clearly records that he also had two concubines Monuma (alias Mu'minah or Hafilah) and Naima (alias Afifah) which we understand, in terms of an Islamic law context, were not maids in the context of slaves. ${ }^{143}$ The concubines have since been accorded the upgraded status of wives by both Dangor ${ }^{144}$ in the latest version of his book and by Ms Sahib, ${ }^{145}$ a descendant of Shaykh Yusuf, on her family tree. As indicated above, the names of Shaykh Yusuf's five daughters as listed in the Company records are (1) Care Sangie; (2) Siety Caeaty; (3) Sanda; (4) Sito Romia and (5) Siety Labieba. 3 of the five names are prefixed with 'Siety' (or Ziety), which, as explained in Section 2, means 'lady', but none of the three names have 'Sara Marouff' attached thereto. It is also clear from the above names of Shaykh Yusuf's five daughters, that Zytie Sara Marouff (Care Sale, or any of her other aliases explained below) is not included among them. However, what may have contributed to the assumption that she was his daughter, was the fact that by the time Shaykh Yusuf's entourage left as a unit in 1704, Zytie Sara Marouff (or Care Sale) also had two children, a son Ibrahim (born in the same year that Shaykh Yusuf died in 1699) and a daughter Sitina Asia born in 1703, and she would have fitted the profile of the 'one woman' who remained behind with 'her two children'.

It will be shown in Section 5, that 1704 is also the time from which the aspersion tarnishing the reputation of Shaykh Yusuf (that it was his grandchildren that converted from Islam) emanated from, and gained further traction through, both 'hearsay' and the interpretations of

143 "According to Islamic Law a man can have 'slave girls' in addition to his wives. The relationship between the master and the 'slave girl' is regulated by the Shariah which defines the rights and duties of both of them." Dangor, Shaykh Yusuf of Makassar, p. 18.

144 Dangor, Shaykh Yusuf of Makassar, p. 18. Its note 32.

145 See the "Explanation of the Composition of the Family Tree of Shaykh Yusuf's offspring" in Musdalifah Sahib, Sheikh Yusuf Al-Makassary: His Life Story As a National Hero From Gowa, South Sulawesi To Cape Town South Africa, and a Reformer In Islamic Mystic World (Ciputat: Orbit Publishing, 2017), pp. 57-9; Dangor, Shaykh Yusuf of Makassar, $3^{\text {rd }}$ edition, p. 86. 
scholars. It has been alleged by scholars that the unnamed 'one woman' and 'her two children' who remained behind was Zytie (aka Care Sale), the daughter of Shaykh Yusuf, and that she decided to forego the opportunity to return to her homeland with her two minor children, because her husband, the Rajah, was unfortunately still being held in exile. Section 6 will refute this argument on the basis of new evidence challenging existing views. Although Zytie's name clearly does not appear to be included in the official list of names of Shaykh Yusuf's 12 children who accompanied to the Cape, Dangor ${ }^{146}$ highlights that it is possible that the Dutch authorities may have recorded her under a different name, because several of the 12 children who came to the Cape are referred to with alternate names. As is also evident from his latest book, while Dangor, ${ }^{147}$ guided by Ms Sahib, a descendant of Shaykh Yusuf, has now been able to clarify in greater detail and extent than before, which children (half sisters and brothers) belonged to which wife (stepmother), we still cannot ascertain exactly how old they were.

It appears that three of the four wives that accompanied Shaykh Yusuf to the Cape (one was deceased) are stated to have been the possible mother of Zytie. One of them, wife number two (Khadijah) hailed from Mecca (in present Saudi Arabia); two wives, wife number five (Care Contoe, also known as Khatijah or Sharifah Fatima) and wife number six (Care Pani) are from Indonesia; and wife number nine (Afifa, also known as Na'imah and labelled a 'concubine') is from Ceylon. As a result, Zytie has been attributed several other contrived aliases, besides 'Care Sale'. Although neither the names 'Sara Marouff' or 'Care Sale' appear on the official list of five daughters that accompanied Shaykh Yusuf to the Cape, and given the four mothers attributed to her, several authors have speculated that Zytie may have been one of the following daughters whose names do appear on the list: 'Siety Romia' (or Zamaniyyah, Puang Amang); 'Care/Kare Mami' (or 'Care Sangie'); or 'Habiba' (or 'Labiebah'). This is explained as follows. It is clearly recorded on the genealogical table or "Family Tree of Shaykh Yusuf's Offspring" compiled in 2017 by Ms Muzdalifah Sahib, a $10^{\text {th }}$ generation Sri Lankan descendant of Shaykh Yusuf currently living in Indonesia, that the King of Tambora

146 Dangor, Shaykh Yusuf of Makassar, $3^{\text {rd }}$ edition, pp. 18-9.

147 Ibid., pp. 85-6. 
was the husband of Zytie. However, Ms Sahib indicates on the same family tree/table that Shaykh Yusuf and his sixth wife, Care Pani, had two daughters, Asyani (also known as Siety Caety) and Zytie, but that Zytie was 'probably' (but not definitely) their daughter. ${ }^{148}$ According to the Company Resolution (30 October 1699) Asyani is listed as being one of five daughters but Zytie's name is omitted. It is also indicated on Ms Sahib's Family Tree that Care Pani, Zytie's 'mother', was herself the daughter of an Indonesian Muslim leader (imam). ${ }^{149}$ If this is so, Zytie's children come from a family of learned Islamic scholars (their maternal grandfather; maternal great-grandfather and possibly their father) which makes their conversion difficult to fathom. While it is unclear how Ms Sahib came to the conclusion that the King was Zytie's husband and why she included Zytie in the Table at all if she did not deem her to be the daughter of Care Pani (and therefore of Shaykh Yusuf), as elaborated below in this Section, Ms Sahib appears to be ambivalent and has reservations that a familial connection existed between Zytie and the Shaykh:

It is strange that while Shaykh Yusuf's family tree includes Zytia Sara Maruf, Muzdalifah [Sahib] assumes that she was not his daughter since she is not listed among his children who arrived at the Cape. ${ }^{150}$

In fact, Ms Sahib is also on record as having expressed a different opinion in 2013. ${ }^{151}$ It appears from a "List of Shaykh Yusuf Al-Makassārî̀s

148 See the "Explanation of the Composition of the Family Tree of Shaykh Yusuf's offspring" by Sahib, Sheikh Yusuf Al-Makassary: His Life Story As a National Hero From Gowa, South Sulawesi To Cape Town South Africa, and a Reformer In Islamic Mystic World, pp. 57-9; Dangor, Shaykh Yusuf of Makassar, $3^{\text {rd }}$ edition, p. 86. See D9 and D5 of Shaykh Yusuf's family tree by M Sahib available on page 86.

149 See B7 of Shaykh Yusuf's family tree by Sahib in Dangor, Shaykh Yusuf of Makassar, $3^{\text {rd }}$ edition, p. 86.

150 Dangor, Shaykh Yusuf of Makassar, $3^{\text {rd }}$ edition, p. 18. Its note 30.

151 For details see Ebrahim Salie, History, Contestations and Commemorations: Shaykh Yusuf al-Makassāri and His Holy Shrine (Kramat) at Faure Eerste River, in Cape Town, South Africa: 1694-1994 (Parts I \& II) (2015), p. 434, https://www.academia. edu/33898816/HISTORY_CONTESTATIONS_AND_COMMEMORATIONS_ SHAYKH_YUSUF_AL-MAKASS $\%$ C4\%80R\%C4\%AA_AND_HIS_HOLY_ SHRINE_KRAMAT_AT_FAURE_EERSTE_RIVER_IN_CAPE_TOWN_SOUTH_ AFRICA_1694-1994._PARTS_I_and_II_, accessed 31 Mar 2020. The author, Mr Salie, 
wives and children" provided by her, that Care Pani was not even under consideration as a possible mother of Zytie. In fact, she indicated that it may even have been possible that Shaykh Yusuf's fifth (and head) wife at the Cape, Care Contoe (also known as Khatijah or Sharifah Fatima), rather than his Sri Lankan concubine (or ninth wife) Afifa (also known as Na'imah), may have been Zytie's mother. Although child marriages may not have been uncommon among the Indonesian aristocracy at the time, and therefore it was not unlikely that Afifa could have been her mother, ${ }^{152}$ Ms Sahib reasoned that if Zytie was born in Ceylon to Afifa, then this would have made her a child bride (aged 10 or 11 years) at the time that she was purported to have married the Rajah of Tamborah. From this we can deduce that Ms Sahib implies that another name for Zytie would not have been Care Mami (also known as Care Sangie and Shagirah), ${ }^{153}$ as that was the name of Afifah's only daughter, but would have been either 'Habiba' or 'Labiebah' which was the name of Care Contoe's only daughter. It appears that her rationale for linking Zytie with Care Contoe could also have been influenced by the fact that the latter was herself the daughter of a Sultan (Ageng Tirtayasa) and that it may have therefore have been fitting that her daughter be the wife of no less than a King. Ms Sahib may also have been influenced by the opinion of Ms Jeffreys ${ }^{154}$ who, as detailed and refuted in Section 5, avers that Cara Contoe herself had said in her petition that she was the mother of Zytie.

indicates that he obtained this 2013 list from an independent researcher of Cape slave history, Mr MG Kamedien, and further that Ms Sahib was a $10^{\text {th }}$ generation descendant of Shaykh Yusuf. As indicated, Ms Sahib subsequently revised this list. For details see Dangor, Shaykh Yusuf of Makassar, $3^{\text {rd }}$ edition, p. 86. See footnotes 107 and 217.

152 This is the view of Mr E Salie. For details see Salie, History, Contestations and Commemorations, pp. 434-5. Text to its note 1029.

153 Dangor, Shaykh Yusuf of Makassar, p. 85. In his version of the 'Family Tree' of Shaykh Yusuf's offspring, also provides these three names for this daughter of Afifa. Local researcher, Delia Robertson, has compiled and developed what is known as the "First Fifty Years Project" which collates, transcribes and publishes copies of Cape of Good Hope records "... relating to individuals who lived at the Cape... during the first decades of the settlement after 1652." According to information on the Project's website, Zytie is also listed under the names of 'Care Sangie' and 'Care Sals'. See. 'Name Index - 8', First Fifty Years: A Project Collating Cape of Good Hope Records, http:/ /www.efamily.co.za/ffy/i8.htm\#s2408, accessed 31 Mar 2020.

154 See text to footnote 251. 
In his anthropological study of Shaykh Yusuf, Abu Hamid, ${ }^{155}$ an Indonesian scholar of note, provides a genealogical table for Shaykh Yusuf in which he lists three daughters (Sitti Samang, aka Puang Ammang; Asyani; and Ince Daeng). This list clearly includes Asyani but excludes Zytie (and all of her aliases). It is therefore quite possible that genealogical tables/family trees, such as the most recent one compiled by Ms Sahib, may have been retrospectively influenced by information deriving from contemporary South African scholarship about Shaykh Yusuf (detailed in Section 5) that indicates both that Zytie was married to the Rajah and may or may not have been Shaykh Yusuf and Care Pani's daughter. ${ }^{156}$ In its turn, it appears from Section 5 that contemporary South African scholarship may also have been retrospectively influenced by early South African scholarship relating to Shaykh Yusuf.

\section{The Family of the Former Rajah in Indonesian and South African Historical Contexts}

Like the Shaykh, the Rajah has been given the toponym 'Tambora'. Company records only refer to the Rajah by the following aliases: 'Nissa Nudum Abdul Rassa'; 'radja van Tambora'; and 'sultan van Tambora'. His wife is referred to as 'Care Sale'. For example, one particular Company Resolution mentions both the names 'Rajah of Tambora' and 'Care Sale'; as well as the names and ages of all their children. The names of the children are also referred to in their baptismal records which however now identify their parents by the different names: 'Abulbasi Sultan' and 'Zytie Sara Marouff'. As a consequence, scholarly sources, most notably Hoge, ${ }^{157}$ through an association of the names in Company records, and linking them with those in the baptismal records, inferred that the Rajah and Abulbasi Sultan were the same person and also that Care Sale and Zytie Sara Marouff were the same person. Two reliable Indonesian sources also give the following alternative names for the Rajah which clearly and

155 Hamid, Syekh Yusuf Makassar, $3^{\text {rd }}$ edition, pp. 129-30. I wish to thank Moulana Tahaa Karaan for making this information available to me.

156 In a Personal communication (15 June 2019) Moulana Tahaa Karaan highlighted that he was inclined to agree with this view.

157 J. Hoge, "The Family of the Rajah of Tambora at the Cape", Africana Notes and News, vol. IX, no. 1 (1951). 
closely resonate with the name 'Abulbasi Sultania' as it appears on the baptismal registers. Donald Tick ${ }^{158}$ refers to the Rajah as 'Nilaauddin Abdul Basyir' while N Marewo ${ }^{159}$ refers to him as 'King Tambora II', 'Nizam ad-Din Abdul al-Bashir' and 'Sultan Bashir' and that he was also nicknamed 'Ronso von Tambora' (which appears to not be correct). ${ }^{160} \mathrm{It}$ appears that the Rajah (or his replacement) was also referred to as 'King of Gorontale'. ${ }^{161}$ For the sake of convenience, the Rajah (who is also sometimes referred to as King) is referred to either as 'Rajah' or 'Rajah of Tambora'.

158 This information was obtained by Stamouers through personal correspondence with Donald Tick. For details see Van Tambora Rajah written by Stamouers. Posted in V - Z available at "Van Tambora Rajah", South Africa's Stamouers, https://www.stamouers.com/stamouers/surnames-v-z/562-van-tambora-rajah, accessed 31 Mar 2020. Donald Tick indicates on his facebook page that he has an interest in preserving information pertaining to the numerous dynasties of Indonesia. His facebook page is available at Donald Tick, Facebook, https://www.facebook.com/ donald.tick/about, accessed 31 Mar 2020.

159 See N. Marewo, 'Tambora dan Strategi Politik Kepentingan Eropa', Radar Sumbawa (19 Apr 2015). Marewo hails from Lombok in Indonesia where he is regarded as a famous artist and man of culture.

160 For details see Delia Robertson, "Rajah of Tambora Albubasi Sultan", First Fifty Years: A Project Collating Cape of Good Hope Records (2014), http://www.efamily.co.za/ffy/g10/p10838.htm, accessed 31 Mar 2020. This site makes reference to a shipping log which contains information of the arrival at the Cape from Batavia of 'Ronso van Tambora' on 28 January 1700 on board the ship 'Voorschoten'. The site indicates that 'Ronso von Tambora' was a political associate of the Rajah and was therefore not another alias for the Rajah himself. For the shipping log. See The Dutch East India Company's shipping between the Netherlands and Asia 1595-1795 (2 Feb 2015), http:// resources.huygens.knaw.nl/das/detailVoyage/96909, accessed 31 Mar 2020.

161 See Leibbrandt, Precis of the Archives of the Cape of Good Hope: Letters Received, 1695-1708, p. 460, Letter (Number 10) Received at the Cape, 30 November 1707, "No. 42, p. 911....List of papers sent to the Cape from Batavia. No. 11. The Radja of Tambora is here called 'King of Gorontale'. As detailed below, although the Rajah of Tambora that was exiled to the Cape hailed from the island of Tambora, interestingly, Gorontalo, currently a province of Indonesia on the island of Sulawesi and formerly part of the province of North Sulawesi, Makassar, the port city from where Shaykh Yusuf hailed and where the Dutch castle 'Fort Rotterdam' was built, is also located on Sulawesi. As alluded to in this section below, such possible connection between the Shaykh and the Rajah is therefore also open for further exploration. See also text to footnote 163 . 
According to the Reverend Francois Valentijn's account of his journey to the Cape (detailed below), the Rajah, who ruled over a small kingdom called Tambora on the Indonesian island of Sumbawa, was 'banished to the Cape because of his bad behaviour on Bima', another VOC trade post located on the same island. ${ }^{162}$ While I do not know whether the Rajah of Tambora was born Muslim or had converted to Islam thereafter, we know that the ruler of the neigbouring state of Bima had converted to Islam in $1615 .{ }^{163}$ Thus, by the time the Rajah was born, the ruler of Bima had been Muslim for some 55 years. The Rajah was exiled to the Cape by a Resolution of the Company in Batavia dated 13 August $1697 .{ }^{164}$ He departed from Batavia on 30 November 1697 on the

162 Liebenberg, Introduction to the Resolutions of Cape of Good Hope, p. 52; François Valentijn, Description of the Cape of Good Hope with the matters concerning it, Amsterdam 1726., ed. by Petrus Serton and E.H. Raidt (Cape Town: Van Riebeeck Society, 1971), pp. 149-53; François Valentijn, "Beschryvinge van de Kaap der Goede Hoope. Deel I”, DBNL (1971), https://www.dbnl.org/tekst/vale003besc01_01/ vale003besc01_01_0005.php\#338\%20(, accessed 31 Mar 2020. I want to thank Moulana T Karaan for drawing my attention to this electronic version of Francois Valentijn's journal. The English translation follows the Dutch version and hence the pages are oddly numbered.

163 "Gorontalo, on the northeastern arm of Sulawesi, had a Muslim ruling class by $1525 \ldots$ The ruler of Bima (Sumbawa) converted to Islam in 1615. All these places were small states and towns." See Taylor, Indonesia, p. 66. See also footnote 161 for reference to 'Gorontale'.

${ }^{164}$ See Leibbrandt, Precis of the Archives of the Cape of Good Hope: Letters Received, 1695-1708, p. 129. Letter (Number One (ii)) Received at the Cape, 30 November 1697, "No 123, p 1087. 'Radja Tambora-The reasons which induced us to hold the Radja of Tambora captive here some time, and as such send him to you with 'Lands Welvaren'," you will find in our Resolution of 13th August last. (See below, No. 20.)" See Letter (Number One (i)) Received at the Cape, 16 August 1697, pages 131 of Leibbrandt's Precis: "No. 20, p. 437. Extract from the general Resolutions of the Castle, Batavia, dated Tuesday, 13th August, 1697. "Radja of Tambora-The Governor-General produced the report of Major Adolf Winckler, the chief merchant M Schenkenberg, and the captain of the Malays, Wan Abdul Bagus, on their further examination of the prisoner, the Radja of Tambora, regarding his attack on the Company's 'paggen' in Bima, and his insolent refusal to receive our letters. He further wished to know what was to be done under the circumstances. After consideration, it was decided to send the Radja to the Cape by the first opportunity, in order to serve as a convict in chains there at the public works, exactly like the other convicts. It was considered that he had deserved death, not only in consequence of his rebellion against the Company, which he had accepted as 
Company ship 'Lands Welvaren' and arrived at the Cape, some three years after Shaykh Yusuf, on 17 February 1698. ${ }^{165}$ It can be inferred from the Company Resolution (dated 24 September 1720) that the Rajah died at the Cape in 1719. Given that he was born around 1670, he was 49 years old at the time of his death. ${ }^{166}$ While both were banned for rebelling against the Dutch, Shaykh Yusuf spent two consecutive periods in exile in different locations in Ceylon and at the Cape. The Rajah, it appears, also spent two periods in exile, and both, quite unusually, at the Cape. "(He) is the only case of repeat political exile to the Cape that appears in the archives. At the time of his second exile, he was not the reigning king of Tambora, and the Company was exercising direct political power in the kingdom in apparent overlordship of the incumbent ruler." ${ }^{167}$ However, it appears from a Company Letter that he had already lost his title when he arrived at the Cape to serve a first period of exile. ${ }^{168}$

his protector, but also in consequence of his vile and evil conduct, by which he had the Queen of Dompo murdered. This conspiracy, he says, he had formed against the king, but that his orders had been wrongly carried out. Also in consequence of the shedding of the blood of so many people who have perished in the war so cruelly and unjustly commenced by him, which caused the ruin and destruction not only of his own, but also of the kingdoms of Dompo and Bima; and further, of the many injustices and disasters which befel the late Radja of Bima, who died here, and had in consequence of that murder, been unjustly banished from his kingdom, and suffered innocently. The above sentence, however, shows him still some mercy." Signed (as a correct copy) by C. v. Swoll, \&e." See J. Hoge, "The Family of the Rajah of Tambora at the Cape", Africana Notes and News, vol. IX, no. 1 (1951), p. 27. See footnote 168.

165 For details see Robertson, "Rajah of Tambora Albubasi Sultan". This site makes reference to a shipping log which contains information of the arrival at the Cape from Batavia of the ship Lands Welvaren which departed from Batavia on 30 November 1697 and arrived at the Cape on 17 February 1698. The site indicates that there were ten political prisoners on board of which the Rajah of Tambora was the most important. For the shipping log see The Dutch East India Company's shipping between the Netherlands and Asia 1595-1795; Ward, Networks of Empire, p. 210.

166 For details see Robertson, "Rajah of Tambora Albubasi Sultan"; Hoge, "The Family of the Rajah of Tambora at the Cape", p. 27. See footnote 224 for the Company Resolution (1720).

167 Ward, Networks of Empire, p. 211.

${ }^{168}$ Leibbrandt, Precis of the Archives of the Cape of Good Hope: Letters despatched, 1696-1708, p. 77. Letter (Number One) Despatched from the Cape, 30 April 1698, "No 123, p1087. The ex-Radja of Tambora, sent hither in the 'Lands Welvaren', we 
Valentijn met the Rajah and his then (unnamed) wife at Governor Willem Adriaan van der Stel's plush residence on the Vergelegen wine estate in 1705. It can be inferred from Valentijn's entry, that the Rajah's wife (who we with hindsight know was named Zytie or Care Sale) followed him to the Cape, and therefore that the two were already married by the time they arrived at the Cape. However, as will be detailed in Section 5, many scholarly sources highlight that the Rajah married Zytie, whom they deem to be the Shaykh's daughter, after his arrival at the Cape. Another source (Kerry Ward) detailed in Section 5 advocates a minority view that the Rajah may have been polygynously married to two women, with Zytie being his first wife, and Care Sale his second, and further that it was the latter's children who apostasised. It is evident from Valentijn's account that Zytie, as Care Sale (or the former Ranee or Queen of Tambora), was obviously also Indonesian, which explains why she may have wanted to return there after the death of her husband.

According to Davids, ${ }^{169}$ the Rajah (like the Shaykh before him), was initially detained and housed in the 'stable of the Castle', but that through the intervention of no less than Shaykh Yusuf, he was transferred to Vergelegen. Although the Rajah only arrived at the Cape three years after the Shaykh, Davids's reference, which appears, as explained below, to be incorrect, and the possible reference to the Rajah as the 'King of Gorantale' (a place located on Sulawesi) are the only indications that the two may have known of each other (maybe already in Indonesia) but not necessarily that they had been in 'contact' at the Cape. Although Davids uses Hoge as a reference, this is not at all what Hoge says. According to Hoge ${ }^{170}$ who cites two Company Letters as his authority (one received dated 16 August 1697, and the other despatched dated 10 March 1708 also referred to below), "The Rajah was sentenced to serve as a convict in chains at the public works but that the Cape government allowed him to live at the Company's garden, 'Rustenburg', or at the stables where the Macassarian exiles of courtly rank are located." As explained below, the

shall, until further orders, treat in accordance with the instructions received at the same time". The reference to 'ex' indicates a loss of status and therefore that he was no longer the Rajah.

169 See Davids, The Mosques of Bo-Kaap, p. 40.

170 Hoge, "The Family of the Rajah of Tambora at the Cape", p. 27. 
latter stables may refer to Ruyterwacht (also spelt Ruiterwacht), which is another Company outpost located in present-day Observatory and which is not too far from Rustenburg (located in present-day Rondebosch). As alluded to in Section 3, and as detailed in Section 6, Company Letters reveal that the Rajah attempted to leave the Cape in 1704 on the same trip as the Shaykh's entourage. This may not necessarily have been coincidental, and may well have been an indication that the two families were aware of each other's plans and therefore may have had some form of communication and relaying of information. Given their status as exiles, and their isolation in separate locations, this did not necessarily mean that their respective families had any physical contact. Further, given that the Rajah arrived in 1698, and Vergelegen may only have been built by 1702, it is unlikely that he lived at the Castle for four years (as opposed to the Shaykh's two months) which is implied in Davids's reference. It is therefore possible that he may have lived at 'stables' ('stal' in Dutch) at another location, called 'ruiterstal' or 'guardhouse', which was the former outpost called Ruyterwacht, ${ }^{171}$ and not at Rustenburg, before relocating to Vergelegen, but could not have gone directly from the Castle to Vergelegen as Davids suggests. Hoge also makes no mention of Shaykh Yusuf. Valentijn indicates in his account that Zytie had some sort of oversight role as housekeeper at Vergelegen, and describes how he enjoyed a delicious fish meal there (a dish that is very common in Indonesia). It is therefore presumed, given her domestic prowess and experience as a cook, and that Islam advocates teetotalism, that it was probably more useful for the Governor that the Tamboras be relocated to Vergelegen from its completion in 1701. Two internet genealogical websites (one ${ }^{172}$ unfortunately no longer has the information available

171 This can be gleaned from Kamedien's translation of the paragraph in Sleigh's book referred to in the text to footnote 35.

172 Maria Dorothea Sultania was born in Rustenburg, Cape, South Africa on 1703 to Rajah Van Tambora and Zytia Sara Moarouff. See "Maria Dorothea Sultania", Ancestry, https://www.ancestry.com/genealogy/records/maria-dorothea-sultania-243bxwhqf, accessed 22 May 2019. This site was last accessed on 22 May 2019 and no longer contains this information. 
on it, and the other is a less credible site ${ }^{173}$ ) indicated that the Rajah's daughter was born at Rustenburg in 1703. If this is the case, it would mean that Zytie resided there at the time of giving birth to her daughter. Upon further enquiry, the Archivist ${ }^{174}$ of the Dutch Reformed Church in South Africa again checked the daughter's baptismal record. However, this record only reflects that she was baptised at the Dutch Reformed Church in Cape Town (in Afrikaans, 'Nederduitse Gereformeerde Kerk' -NGK, Kaapstad). Unfortunately, time and the Covid-19 crisis, did not permit further enquiry at the State Archives in Cape Town, to determine the address records of her parents at that stage.

According to Sleigh, ${ }^{175}$ the Rajah and his family were relocated to reside at Rustenburg in Rondebosch only after the Governor was relieved of his duties and left the Cape in 1706. This was not unsual because other Indonesian exiles of high rank were already also housed there. ${ }^{176}$ A Company Letter dated 10 March 1708 indicated that at the time he may have lived permanently “.... at the Company's garden, 'Rustenburg', or at the stables (Ruyterwacht), where the Macassarian exiles of courtly rank are located". ${ }^{177}$ He must therefore have been residing there when he was pardoned and departed for Indonesia in 1710. According to a Company Resolutions (dated 26 February 1710), ${ }^{178}$ the Rajah, who was

173 According to a WikiTree Family Tree 'Sitina Asia Dorothea (Sultan) van den Bosch (1703-1741)' was '(b)orn (in) 1703 in Rustenburg'. See 'Sitina Asia Dorothea (Sultan) van den Bosch (1703-1741)", WikiTree Family Tree, https:/ /www.wikitree.com/ wiki/Sultan-13, accessed 31 Mar 2020.

174 Personal communication with Archivist Collette de Wet (17 March 2020).

175 Sleigh, Die buiteposte, p. 234. I wish to express my appreciation to Ebrahim Rhoda for referring me to this source. This was not unsual because Sleigh indicates that other Indonesian exiles of high rank were already also housed there.

176 Sleigh, "Die buiteposte van die V.O.C. aan die grens van die Kaapse nedersetting, 1652-1707”, p. 145. Also highlights that in 1680 about 30 Macaresse exiles, mostly nobility, were housed at Rustenburg.

177 See Letter (Number Twelve) Despatched from the Cape, 10 March 1708, page 343 of Leibbrandt's Precis in footnote 190 below.

178 "Radja Tambora, ao. Sent here in 1698 on account of his advanced age and the good testimony of the Lord Governor and Council, with his wife." See Resolutions of the Council of Policy of Cape of Good Hope Cape Town Archives Repository, South Africa, no. C. 27 (1710), http://databases.tanap.net/cgh/make_pdf.cfm?artikelid=21548, accessed 
banished to the Cape in 1698, was pardoned and allowed to go home with his wife. No mention is, however, made of their two children who would have been born by then. The following two entries in Valentijn's account, pertaining to the Rajah and the Shaykh, respectively, are quoted in full below, given that they provide both a rare glimpse into their lives and key clues in support of the main argument in this article that Care Sale (or Zytie), who is also not referred to by name in Valentijn's account below, but who we with hindsight now know from a Company Resolution and baptismal records (detailed in Section 7) was the Rajah's wife, may not have been the daughter of Shaykh Yusuf:

Willem Adriaan van der Stel set here his magnificent country-estate Vergelegen in 1700 or 1701, 12 miles from the Castle...I saw this lovely building in 1705, (on Monday 5 November) two days before leaving for the Indies (Wednesday 7 November $\left.{ }^{179}\right)$...I had agreed to preach on Sunday (4 November) afternoon at the Castle, and since the Governor could find no time that morning to show me this estate, H.E. asked me the day before (Saturday 3 November) if I would wish to make the trip with him after the sermon. I agreed, accepting this offer with much gratitude. We left at 6 in the evening (Sunday 4 November) in a coach with 6 horses, and after driving very fast for 3 hours and taking a small meal, we changed them for 6 fresh horses, and arrived at Vergelegen at 12 o'clock at night (Monday 5 November). Next day (still Monday 5 November) I viewed this lovely homestead...To my surprise I found here the King of Tambora $\left({ }^{180}\right)$ and his wife, of whom we tell more fully in writing of the affairs of Macassar and Batavia. $\left.{ }^{(81}\right)$ He was busy writing out the Coraan or Alcoraan very neatly for H.E., (His Excellency) and his wife had some sort of oversight over the household. He was banished here because of his bad behaviour

25 May 2019. I would like to thank Professor F du Toit for the free translation of this extract from the old Dutch. See text to footnote 243 where Jeffreys appears to refer to this Resolution.

179 In terms of p. 150, note 123 of this account, Valentijn departed for Batavia on 7 November 1705. See Valentijn, Description of the Cape of Good Hope with the matters concerning it, Amsterdam 1726., pt. 1.

180 In terms of $\mathrm{p} 150$, note 127 of this account (Google translation into English), Tambora and Bima were states on the north coast of the island of Sumbawa (Lesser Sunda Islands).

181 However, it appears from page 152, note 128 (on page 152) of this account (Google translation into English) that: 'No other description was found in Valentine.' 
on Bima, and she followed for love of him. They were glad to see me, so that they could speak with me there for some time in the Malay tongue, and the Governor was much astonished to hear how, after being so long out of the Indies, I still spoke so fluently. This house was demolished by H.E., by orders of the Lords and Masters, somewhat after 1710. After I had spent that day rejoicing my heart with the sight of so very many beauties, and being refreshed by choice and tasty steenbrassem and other rare fish, as also the noblest fruits imaginable, and by a lovely glass of wine from HE's own wine-press, at 6 o'clock (pm) we took up the journey again, and drove with the same coach and horses back to the Castle, where we arrived about 12 (midnight leading to Tues 6 November), and where I heartily thanked HE for the courtesy shown me. I should have wished to drive once by day over this road, but this was not possible, and also after my return I found no opportunity thereto. ${ }^{182}$

"Heer (Lord) Kalden had a property called Zandvliet, lying a few miles from the Castle below Stellenbosch...I was there, and noticed... two things that gave me cause for wonder. One was the grave of the renowned Sjeich Joesef (of whom we speak more fully in dealing with Java and Macassar) ${ }^{183}$ who was banished here and died near here, and is buried and honoured with an ornamental Moslem tomb, built up very high of stones."184

It is clear from the first entry above that Valentijn must have been on friendly terms with the Governor (as he was with his father) to be extended an invitation to his country estate. Sleigh's account of Valentijn's two prior visits (in 1685 and 1695) confirms this. Valentijn also does not identify the Rajah's wife by name but only by her status as his wife. The fact that she devotedly 'followed' him out of 'love' from Bima (Sumbawa) implies that she was Indonesian and came from a different location to that of Shaykh Yusuf's family (Makassar), and further, that their marriage was

182 See Valentijn, Description of the Cape of Good Hope with the matters concerning it, Amsterdam 1726., pp. 149-53.

183 This statement and the fact that in footnote 46 on page 201 of this account further reference is made to Shaykh Yusuf in Part 4, page 123, are indications that Valentijn may also have been familiar with Shaykh Yusuf's role as a freedom fighter who led a guerrilla war against the Company in Batavia. See footnote 244.

184 See Valentijn, Description of the Cape of Good Hope with the matters concerning it, Amsterdam 1726., pp. 199-201. 
not entered into at the Cape. If, as indicated in Section 2, Valentijn spent 39 days at the Cape during this third visit, and it must have been during this time, between his arrival on 29 September and his departure on 7 November 1705, that he also saw the grave of Shaykh Yusuf at Faure. This visit would have occurred before his visit to Vergelegen, especially given his departure from the Cape so shortly thereafter. It appears that during his visit to Vergelegen on 5 November 1705 no mention was made of Shaykh Yusuf by Valentijn, nor was any association with him alluded to by the Tamboras. Given that the prospect of speaking with someone in their mother tongue (Malay) was welcomed by his wife, is a further indication that she was not a local woman. There was clearly no language barrier that could have prevented the Tamboras from asking questions about the family of Shaykh Yusuf (their alleged relatives) or Valentijn providing information about having visited his grave (or even that he knew of Shaykh Yusuf's role in Indonesia as he clearly did $\left.{ }^{185}\right)$. It could also allude to the fact that, in spite of the proximity of their respective residences which at the time were both located in the same district (Stellenbosch), because of their isolation, there may not have been much, if any, contact between the Tamboras and the Shaykh's family before his entourage departed in 1704 (when the Rajah is also mentioned in Company Letters as attempting to depart with them). Although by 1705 the Shaykh had already been dead for six years, the fact that their respective families may have been on good terms with the then Governor (Willem Adriaan), and his father (Simon), would have been of little consequence because ultimately the Rajah was a political exile, and exceptions to Company rules which would not have allowed such contact, would have been frowned upon and not tolerated. As indicated in Section 2, Valentijn's own interest in translating the Bible into Melayu may have resulted in his vivid recalling of the Rajah's transcribing of the Qur'an.

However, some sources have embellished Valentijn's account with details (that it was transcribed into 'Dutch' and 'from memory') ${ }^{186}$ that

185 See footnotes 183 and 244.

186 See Kamedien's translation of Sleigh, Die buiteposte, p. 234. Where Sleigh indicates that "...the Rajah translated the Koran into Dutch". In the following sources Ward indicates that the Rajah had transcribed the Qur'an from memory. See Ward, Networks of Empire, p. 210; Kerry Ward, "Southeast Asian Migrants", in Cape Town 
are not contained in it; we cannot therefore assume from this account that it was transcribed into Dutch (the language of his capturer) from either Arabic or Malay because there is no indication to that effect, nor that it was done from memory. The Rajah's copy has since then not been located. However, there are diverse views of what may have happened to the Rajah's Qur'an. ${ }^{187}$ Nonetheless, the Rajah is speculated to have been Between East and West: Social Identities in a Dutch Colonial Town, ed. by Nigel Worden (Cape Town: Jacana Media, 2012), p. 89. See text to footnotes 256 and 257 for quotations from these respective sources to this effect.

187 According to Davids, The Mosques of Bo-Kaap, p. 40. "( $t$ )his Qur'an, the first written in the Colony, probably never left Vergelegen.” Prompted by an illuminating conversation with Shaykh Ridwan Rylands, I learnt of the following 'hearsay' or orally transmitted views. The assumption that the Rajah's Qur'an may have been returned to the custody of Cape Muslims by a Dutchman was fortuitously first brought to my attention by Imam Adam Philander, the Imam of the Nurul Latief mosque located in Macassar, Faure near the shrine of Shaykh Yusuf. Imam Philander, who had in 2012 received initiation (baya) into the Khalwatiyyah Sufi order of Shaykh Yusuf by a $9^{\text {th }}$ generation descendant of the Shaykh, believes that this could possibly also have been Shaykh Yusuf's Qur'an. The Imam had, in his turn, been personally informed of this by his colleague and friend, the late Moulana Yusuf Karaan of the Strand, to whom it was, after its receipt, initially brought to for verification and/or safekeeping. Further, that after the death of Moulana Karaan in 2015, it was held in the custody of his son Professor Abdus Salam Mohammed Karaan. (Personal Communication, 21 April 2020). Upon further enquiry from the Cape-based community historian, Mr E Rhoda, he shed further light and explained the unusual context of the circumstances in which the alleged Rajah's Quran, or rather a part of it, and written in pure Arabic script, was returned to a random person, because he was dressed in Muslim garb, in the Somerset Mall, in Somerset West near to the vicinity of Strand (where Moulana Karaan lived) and not too far from Vergelegen in Stellenbosch (in the opposite direction) where the Rajah had resided at the time of writing it. Mr Rhoda confirmed that pages of the Qur'an were sent for testing to verify its age and authenticity but that according to the specialist it was sent to the type of paper that was used was not available at the Cape at that time but may have been available later (possibly in the 1800s). Further that the person to whom it was originally given into custody at the shopping mall (whom we know in hindsight was a former student of Mr Rhoda, Moulana Muhammad Chotia) had in fact requested that it be returned to him, which it apparently was. It is therefore now in his custody (Personal communication, 22 April 2020). It is on the basis of his extensive knowledge and research that I therefore requested Mr Rhoda to undertake the task of verifying the information pertaining to the 'Rajah's' Qur'an, that he relayed to me, with Professor Karaan. I also sent Moulana Tahaa Karaan (his brother) a Whatsapp message on 22 April 2020 to also verify and shed light on the mystery surrounding the above Qur'an. Given their understandably busy schedules, as at 28 April 2020, both Mr Rhoda 
the first person at the Cape to have penned a copy of the Qur'an. He was clearly afforded both time and material resources to do so. This implies that he was likely to have been an educated man, but not necessarily that he had memorised the Qur'an (hafir) like Shaykh Yusuf had. The next handwritten copy of the Qur'an was only penned some 75 years later by another royal political exile and hafir, Tuan Guru, who was banished to the Cape from Indonesia in $1780 .{ }^{188}$ We can assume, given that Islam was allowed at the time to be practised in private, that exiles may have been permitted to have access to religious books like the Qur'an, which is akin to the Bible for Muslims. On the other hand, correspondence to and from Batavia may have justifiably been prohibited for political prisoners. It appears from Company records that desperate attempts by the Rajah, in $1707 .{ }^{189}$

and I were unfortunately still awaiting feedback from the Karaan brothers to verify our above understanding. Any errors in our understanding, therefore, remain our own.

188 Shafiq Morton, From the Spice Islands to Cape Town: The Life and Times of Tuan Guru (South Africa: National Awqaf Foundation of South Africa, 2018), pp. 44-5.

189 See Leibbrandt, Precis of the Arcbives of the Cape of Good Hope: Letters received, 1695-1708, p. 460. Letter (Number Nine) Received at the Cape, 22 October 1707, "No 41 p. 907 ....Extract from the letter from Macassar about the Radja of Tambora. See despatch No. 34.... The Governor could not decide to send the letters to the chiefs of Tambora, and the Council on the 15th January decided to have them opened and translated. The first letter contained the request of the exile to us, that we might intercede for him with the Batavia Government, that he may be set at liberty, and sent back to his country. In that to his friends, he complains bitterly of the injustice done to him, and that the present King of Tambora Dain Manangon, whom he looks upon merely as a 'Boumi Soro', or beach governor, a position with which he ought to have been satisfied, had been unjustly placed in his stead. Many more expressions of the like were in the letter, not one of the best odour, and which would not be very edifying to the kings and other chiefs of 'Cumbawa'. We therefore, on the 25th February, decided not to forward the last mentioned letter, but to file it among our secret papers, and send the translation to you (Batavia Council). You will gather from it that the Radja enjoys rather too much freedom at the Cape, and is able to have free access to all the ships. In our opinion this ought to be quite different, as we do not believe that you will ever resolve to let this rebel and murderous prince ever return to his own country." My emphasis. Ibid,, p. 458. See Letter (Number 10) Received at the Cape, 30 November 1707, "No. 34, p. 857. From Batavia...Enclosed you will find an extract from a letter of the Governor and Council at Macassar of the 22nd October last, to this Government, from which you will gather that in two ways there fell into their hands two distinct Malay letters written by the Radja of Tambora, exiled at the Cape; the one to his Honour, and the 
He did it again in $1708^{190}$ before his death in $1719,{ }^{191}$ to send letters to Batavia were intercepted and unsuccessful.

According to Van Rensburg:

"On the 20th August 1713 (or 25 December 1713) Rajah was sent from Batavia again back to the Cape...His wife and children must have accompanied him back to the east and then returned with him to the Cape, this is devotion. He returned to the Cape (3 April 1714)...(with) another 8 persons from Tambora (who) were also banished." 192

There is no indication that these 8 (or 20 according to Sleigh) actually formed part of the Rajah's entourage. The Rajah is deemed to have wedded Shaykh Yusuf's daughter, Zytie Sara Marouff, at the Cape soon after his arrival in 1698 but shortly before the death of her father in 1699. If this marriage did take place, then it could be deemed to have other to certain influential people of the territory, from which can be gathered the dissatisfied mind of that exile, whom you have allowed too much liberty of communication with those of the passing vessels; and as with those of Macassar we have good reasons to judge that these things should not be allowed, you are herewith ordered to confine the liberty of that individual, and to take care that all communication is cut off between him and the passing ships, especially those on board foreign ships. . . Arrival of the 'Ter Aa' from Mauritius." My emphasis.

190 Letter (Number Twelve) Despatched from the Cape, 10 March 1708, page 343 of Leibbrandt's Precis: 'We will take good care of the exiled King of Tambora, that he has no communication with the passing ships, especially foreign ones, in order so to cut off all communication between him and his countrymen. He seldom has a chance, however, as he lives permanently at the Company's garden, 'Rustenburg', or at the stables, where the Macassarian exiles of courtly rank are located. Should he, however, wish to write, it will be difficult to prevent him, unless he is closely confined and watched.'

191 “The Noble Lord Governor produced a certain letter of the banned Radja Tambora at the meeting. Tambora was affectionate with the director of the fort, Pieter Gijsbert Noodt (who later became Governor at the Cape from 25 February 1727 to 23 April 1729). The Governor had to decide whether or not to allow Noodt to leave for Batavia. Noodt was placed in a difficult situation because of this and therefore the Council is called upon to decide whether Noodt should leave or whether he should stay. A communication in this regard will be sent by the first ship to the address of his Highness the Lord Governor Zwaardecroon." See Resolutions of the Council of Policy of Cape of Good Hope Cape Town Archives Repository, South Africa, no. C. 49 (1719), http:/ / databases.tanap.net/cgh/make_pdf.cfm?artikelid=22182, accessed 31 Mar 2020. I would like to thank Professor F du Toit for the free translation of this extract from the old Dutch and Prof J de Visser for confirming it.

192 Van Rensburg, "Shaykh Yusuf's Familia”, p. 199. 
been a good match because of the alliance it would have created between two royal families from different locations in Indonesia. Shaykh Yusuf was a Sunni scholar, "... a strict adherent of the shari'ah", ${ }^{193}$ and both a follower of the Shafi'i madzhab (school of legal thought) and an expert in its jurisprudence. In terms of this school of law, such a marriage must have had his stamp of approval. This implies that it would have been possible for him as the father of a bride and her guardian (wall) to give his daughter's hand in marriage to a man by proxy through a legal representative (waki) without either he (the father) or the bride having to be present at the marriage ceremony (nikah) in order for it to be valid. ${ }^{194}$ Thus, if Zytie (Care Sale) was the Shaykh's daughter, and a marriage between her and the Rajah did take place at the Cape as is reported by some scholars to be the case, then the following questions arise, for which these sources provide no clear answers: when, where and how did such marriage take place if the Shaykh and the Rajah were held in isolation, at different locations, precisely so that they could not have contact with each other? ${ }^{195}$

As indicated, the Rajah passed away in 1719. Van Rensburg ${ }^{196}$ estimates that he died in the latter part of 1719 because of indications in Company Letters, sent to Batavia dated 17 October and 16 December 1719, that he had died. In terms of a Company Resolution (dated 24 September 1720), ${ }^{197}$ to be detailed in Section 5, his widow, who is referred to as Care Sale and aged 41 in the Resolution, had pleaded dire poverty and requested to return to Indonesia with her children but her request was, unfortunately, denied. The Resolution also mentions their five children by name and age as follows: four sons (Ibraim Adaham, aged 21; Mochamat

193 Dangor, Shaykh Yusuf of Makassar, $3^{\text {rd }}$ edition, p. 64..

194 For details see Najma Moosa and Muneer Abduroaf, "Implications of the Official Designation of Muslim Clergy as Authorised Civil Marriage Officers for Muslim Polygynous, Interfaith and Same-Sex Marriages in South Africa", in The International Survey of Family Law, ed. by Fareda. Banda and Margareta F. Brinig (Bristol: LexisNexis, 2017), pp. 341-6.

195 Dangor, Shaykh Yusuf of Makassar, p. 64. He relies on Jeffreys, "The Malay Tombs of the Holy Circle - VI: The Kramat at Zandvliet, Faure, Part 2: Sheik Joseph at the Cape". as a source.

196 Van Rensburg, "Shaykh Yusuf's Familia”, p. 199.

197 For a translation of this Company Resolution see text to footnote 224. 
Aseek, aged 9; Mochamat Daijan, aged 7; and Mochamat Asim, aged 4) and a daughter (Sitina Asia, aged 17). From this Resolution, and their father's two periods of exile (1698 to 1710 and 1714 to 1719), we can estimate the dates and places of their birth. If in 1720 Ibraim Adahan was 21 years old, his estimated date of birth was in 1699 at theCape when his mother, Zytie (or Care Sale), was 20 years old. In the same vein, Sitina Asia was born in 1703 at the Cape when her mother was 24. Mochamat Aseek was born in 1711 (probably in Indonesia) when Zytie was 32, Mochamat Daijan was born in 1713 (also probably in Indonesia) when Zytie was 34, and her youngest child, Mochamat Asim, was born in 1716 at the Cape when Zytie was 37. The conversion of their children to Christianity is detailed in Section 7.

TO BE CONTINUED 


\section{BIBLIOGRAPHY}

Ajam, M.T., "Hajee Sulaiman Shah Mohamed: A South African Philanthropist (d. 1929)", Journal for Islamic Studies, vol. 10, 1990, pp. 68-76.

"Areca nut", Wikipedia, https://en.wikipedia.org/w/index. php?title=Areca_nut\&oldid=968036123, accessed 31 Mar 2020.

Assim, Usang M. and Julia Sloth-Nielsen, "Islamic Kafalah as an Alternative Care Option for Children Deprived of a Family Environment", African Human Rights Law Journal (AHRLJ), vol. 14, no. 2, 2014, pp. 322-45.

Azra, Azyumardi, The Origins of Islamic Reformism in Southeast Asia: Networks of Malay-Indonesian and Middle Eastern 'Ulama' in the Seventeenth and Eighteenth Centuries, Crows Nest, NSW: Allen \& Unwin, 2004.

"Batak: people", Encyclopedia Britannica, https://www.britannica.com/ topic/Batak, accessed 31 Mar 2020.

Bedaux, J.B., "The Portraits of Simon van der Stel, First Governor of the Cape", Stellenbosch Papers in Linguistics, vol. 17, 1988, pp. 1-18.

Bradlow, Muhammad 'Adil, "Imperialism, State Formation and the Establishment of a Muslim Community at the Cape of Good Hope, 1770-1840: A Study in Urban Resistance", Master Thesis, Cape Town: University of Cape Town, 1988.

Colvin, Ian D., Romance of Empire South Africa, London: Caxton Pub. Co, 1909.

Dangor, Suleman Essop, "A Critical Biography of Shaykh Yusuf”, Master Thesis, Durban, South Africa: University of KwaZulu-Natal, 1981.

----, Shaykh Yusuf of Makassar, Durban: Iqra Publishers, 1994.

----, Shaykh Yusuf of Makassar, 3rd edition, Durban: Digniti, 2019.

Davids, Achmat, The Mosques of Bo-Kaap: A Social History of Islam at the Cape, Cape Town: South African Institute of Arabic and Islamic Research, 1980.

Donald Tick, Facebook, https://www.facebook.com/donald.tick/about, accessed 31 Mar 2020.

Du Plessis, I.D., The Cape Malays: History, Religion, Traditions, Folk. Tales: 
The Malay Quarter, 3rd. edition, Cape Town: A. A. Balkema, 1972. "Dutch East India Company (DEIC)/VOC", South African History Online, https://www.sahistory.org.za/article/dutch-east-india-companydeicvoc, accessed 31 Mar 2020.

"Ebook Precis of the archives of the Cape of Good Hope (Volume 17) by Cape of Good Hope (South Africa)", ebooksread, http://www. ebooksread.com/authors-eng/cape-of-good-hope-south-africaarchives/precis-of-the-archives-of-the-cape-of-good-hope-volume17-ala.shtml, accessed 31 Mar 2020.

Ebrahim, Mogamat Hoosain, "The Transformation in the Management and Traditions of Hajj at the Cape", PhD. Dissertation, Durban, South Africa: University of KwaZulu-Natal, 2007.

Gauteng correspondent, "Descendants of Shaikh Yusuf of Makassar on Goodwill Visit to SA", Muslim Views, 23 Jun 2017.

Graham, Duncan, “'Bandit Saints of Java': Where Islam meets Local History", The Jakarta Post, 15 Mar 2019, https:/ / www.thejakartapost. com/life/2019/03/14/bandit-saints-of-java-where-islam-meetslocal-history.html, accessed 31 Mar 2020.

Greyling, Christeman Joel Andries, "Schech Yusuf, the Founder of Islam in South Africa", Religion in Southern Africa, vol. 1, no. 1, 1980, pp. 9-22.

----, "Die Invloed van Strominge in die Islam op die Jesusbeskouing van die Suid-Afrikaanse Moslems", PhD. Dissertation, Stellenbosch: Stellenbosch University, 1976.

Haan, Frederik de, Priangan: De Preanger-Regentschappen onder het Nederlandsch Bestuur tot 1811, vol. 3, Batavia: Bataviaasch Genootschap van Kunsten en Wetenschappen, 1912.

Hamid, Abu, Syekh Yusuf Makassar: Seorang Ulama, Sufi dan Pejuang, Jakarta: Yayasan Obor Indonesia, 1994.

Haron, Muhammed, "Three Centuries of NGK Mission amongst Cape Muslims: 1652-1952”, Journal of Muslim Minority Affairs, vol. 19, no. 1, 1999, pp. 115-23 [https://doi.org/10.1080/13602009908716428].

Hoge, J., "The Family of the Rajah of Tambora at the Cape", Africana Notes and News, vol. IX, no. 1, 1951. 
Jaffer, Mansoor (ed.), Guide to the Kramats of the Western Cape, 3rd edition, Cape Town: Cape Mazaar Kramat Society, 2010.

Jappie, Saarah, "Between Makassars: Site, Story, and the Transoceanic Afterlives of Shaykh Yusuf of Makassar", PhD. Dissertation, Princeton, N.J: Princeton University, 2018.

Jeffreys, M.K., "The Malay Tombs of the Holy Circle - VI: The Kramat at Zandvliet, Faure, Part 2: Sheik Joseph at the Cape", The Cape Naturalist, vol. 1, no. 6, 1939, pp. 195-199.

Jeppie, Shamil, "Commemorations and Identities: The 1994 Tercentenary of Islam in South Africa", in Islam and the Question of Minorities, ed. by Tamara Sonn, Atlanta, Ga: Scholars Press, 1996, pp. 73-91.

Kamedien, M.G., "Raja of Tambora \& Joseph at Macassar", rootsweb, 6 Nov 2001, https://lists.rootsweb.com/hyperkitty/list/southafrica@rootsweb.com/thread/11320360/, accessed 31 Mar 2020.

"Legacy of Slavery: Heritage of Slavery", Iriko Museums of South Africa, https://slavery.iziko.org.za/legacyofslavery, accessed 31 Mar 2020.

Leibbrandt, H.C.V., Precis of the Archives of the Cape of Good Hope: Letters Received, 1695-1708, Cape Town: W.A. Richards \& Sons, 1896, http://archive.org/details/precisofarchives00cape_3, accessed 31 Mar 2020.

----, Precis of the Archives of the Cape of Good Hope: Letters Despatched, 16961708, Cape Town: W. A. Richards \& sons, 1896, http:/ /archive.org/ details/precisofarchives00cape_1, accessed 31 Mar 2020.

----, Precis of the Archives of the Cape of Good Hope: The Defence of Willem Adriaan van der Stel, Cape Town: W. A. Richards \& sons, 1897, http:/ / archive.org/details/precisofarchives00leib, accessed 31 Mar 2020.

----, Precis of the Archives of the Cape of Good Hope: Requesten (Memorials) 1715-1806, vol. 2, Cape Town: Cape Times, 1905.

Liebenberg, Helena, Introduction to the Resolutions of Cape of Good Hope, Cape Town: TANAP.

Loos, Jackie, Echoes of Slavery: Voices from South Africa's Past, Cape Town: David Philip, 2004.

Lubis, Nabilah, "Min A'lāmi Indūn̄isìya: al-Shaykh Yūsuf al-Makassarī (1626-1699)", Studia Islamika, vol. 1, no. 3, 1994 [https://doi. 
org/10.15408/sdi.v1i3.852].

Mahida, Ebrahim Mahomed, History of Muslims in South Africa: A Chronology, Durban: Arabic Study Circle, 1993.

Marewo, N., "Tambora dan Strategi Politik Kepentingan Eropa", Radar Sumbawa, 19 Apr 2015.

"Maria Dorothea Sultania", Ancestry, https://www.ancestry.com/ genealogy/records/maria-dorothea-sultania-24-3bxwhqf, accessed 22 May 2019.

Melletpt, "The Story of the First Two 'Coloured' Governors at the Cape - Simon \& Willem”, Camissa People, 17 May 2016, https:// camissapeople.wordpress.com/2016/05/17/the-story-of-the-firsttwo-coloured-governors-at-the-cape-simon-willem/, accessed 31 Mar 2020.

Moosa, Ebrahim, "Descendants of Sheikh Yusuf visit Johannesburg", Radio Islam, 27 Apr 2017, https://www.radioislam.org.za/a/ descendants-of-sheikh-yusuf-visit-johannesburg/, accessed 31 Mar 2020.

Moosa, Najma, "The Dissolution of a Muslim Marriage by Divorce", in The Law of Divorce and Dissolution of Life Partnerships in South Africa, ed. by Jacqueline Heaton, Cape Town: Juta \& Co Ltd, 2014.

Moosa, Najma and Muneer Abduroaf, "Implications of the Official Designation of Muslim Clergy as Authorised Civil Marriage Officers for Muslim Polygynous, Interfaith and Same-Sex Marriages in South Africa", in The International Survey of Family Law, ed. by Fareda. Banda and Margareta F. Brinig, Bristol: LexisNexis, 2017.

Morton, Shafiq, From the Spice Islands to Cape Town: The Life and Times of Tuan Guru, South Africa: National Awqaf Foundation of South Africa, 2018.

"Name Index - 8", First Fifty Years: A Project Collating Cape of Good Hope Records, http://www.e-family.co.za/ffy/i8.htm\#s2408, accessed 31 Mar 2020.

Plug, C., "Valentijn, François (geography)", S2A3 Biographical Database of Southern African Science, http://www.s2a3.org.za/bio/Biograph_final. php?serial=2901, accessed 31 Mar 2020. 
Quinn, George, "Where History Meets Pilgrimage: The Graves of Sheikh Yusuf Al-Maqassari and Prince Dipanagara in Madura", Journal of Indonesian Islam, vol. 3, no. 2, 2009, pp. 249-66 [https:// doi.org/10.15642/JIIS.2009.3.2.249-266].

Resolutions of the Council of Policy of Cape of Good Hope Cape Town Archives Repository, South Africa, Reference code: C, 1694, http://databases. tanap.net $/$ cgh/make_pdf.cfm?artikelid=21548, accessed 31 Mar 2020.

----, no. C. 27, 1710, http://databases.tanap.net/cgh/make_pdf. cfm?artikelid=21548, accessed 25 May 2019.

----, no. C. 49, 1719, http://databases.tanap.net/cgh/make_pdf. cfm?artikelid=22182, accessed 31 Mar 2020.

Robertson, Delia, "Rajah of Tambora Albubasi Sultan”, First Fifty Years: A Project Collating Cape of Good Hope Records, 2014, http://www.efamily.co.za/ffy/g10/p10838.htm, accessed 31 Mar 2020.

Roux, Schalk W. le, "Die Kramat van Sjeg Yusuf, Faure", Kramat of Sheikh Yusuf, 2013, https://www.artefacts.co.za/main/Buildings/ bldgframes.php?bldgid=10977, accessed 31 Mar 2020.

Sahib, Musdalifah, Sheikh Yusuf Al-Makassary: His Life Story as a National Hero from Gowa, South Sulawesi to Cape Town South Africa, and a Reformer in Islamic Mystic World, Ciputat: Orbit Publishing, 2017.

Salie, Ebrahim, History, Contestations and Commemorations: Shaykh Yusuf al-Makassäri and His Holy Shrine (Kramat) at Faure Eerste River, in Cape Town, South Africa: 1694-1994 (Parts I \& II), 2015, https:// www.academia.edu/33898816/HISTORY_CONTESTATIONS_ AND_COMMEMORATIONS_SHAYKH_YUSUF_AL-

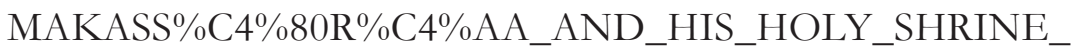
KRAMAT_AT_FAURE_EERSTE_RIVER_IN_CAPE_TOWN_ SOUTH_AFRICA_1694-1994._PARTS_I_and_II_, accessed 31 Mar 2020.

Samuelson, Meg, “Orienting the Cape: A 'white' Woman Writing Islam in South Africa", Social Dynamics, vol. 37, no. 3, 2011, pp. 363-78 [https://doi.org/10.1080/02533952.2011.655034].

"Sheik Yusuf (1626 - 1699)", The Presidency, http:/ /www.thepresidency. 
gov.za/national-orders/recipient/sheik-yusuf-1626-1699, accessed 31 Mar 2020.

"Simon van der Stel", Wikipedia, https://en.wikipedia.org/w/index. php?title=Simon_van_der_Stel\&oldid=954229072, accessed 31 Mar 2020.

"Sitina Asia Dorothea (Sultan) van den Bosch (1703-1741)", WikiTree Family Tree, https://www.wikitree.com/wiki/Sultan-13, accessed 31 Mar 2020.

"Slavery and Emancipation of Slaves", South African History Online, https://www.sahistory.org.za/article/slavery-and-emancipationslaves, accessed 31 Mar 2020.

Sleigh, Daniel, "Die Buiteposte van die V.O.C. aan die Grens van die Kaapse Nedersetting, 1652-1707”, Master Thesis, Stellenbosch: Stellenbosch University, 1982.

----, Die Buiteposte: VOC-buiteposte onder Kaapse bestuur 1652-1795, Pretoria: Haum, 1993.

South African Government, The Constitution of the Republic of South Africa. Taylor, Jean Gelman, Indonesia: Peoples and Histories, New Haven \& London: Yale University Press, 2003.

Tayob, Abdulkader I., Islam in South Africa: Mosques, Imams, and Sermons, Gainesville: University Press of Florida, 2009.

The Dutch East India Company's Shipping between the Netherlands and Asia 1595-1795, 2 Feb 2015, http://resources.huygens.knaw.nl/das/ detailVoyage/96909, accessed 31 Mar 2020.

Upham, Mansell George, "At War with Society...Did God hear? The Curious Baptism in 1705 of a 'Hottentot' Infant Named Ismael", Capensis, vol. 4, 2000, pp. 29-51.

Valentijn, François, Description of the Cape of Good Hope with the Matters Concerning it, Amsterdam 1726, ed. by Petrus Serton and E.H. Raidt, Cape Town: Van Riebeeck Society, 1971.

----, "Beschryvinge van de Kaap der Goede Hoope. Deel I", DBNL, 1971, https://www.dbnl.org/tekst/vale003besc01_01/ vale003besc01_01_0005.php\#338\%20(, accessed 31 Mar 2020.

Van Rensburg, André M., "Shaykh Yusuf's Familia”, Familia, vol. 39, no. 
4, 2002, pp. 195-204.

----, "The Enigma of Shaykh Yusuf's Place of Burial", Quarterly Bulletin of the National Library of South Africa., vol. 57, no. 2, 2003, pp. 70-85.

"Van Tambora Rajah", South Africa's Stamouers, https://www.stamouers. $\mathrm{com} /$ stamouers/surnames-v-z/562-van-tambora-rajah, accessed 31 Mar 2020.

Villette, Francesca, “31 Kramats Considered for Heritage Status”, IOL, 3 May 2019, https://www.iol.co.za/capetimes/news/31-kramatsconsidered-for-heritage-status-22404699, accessed 31 Mar 2020.

Ward, Kerry, Networks of Empire: Forced Migration in the Dutch East India Company, Cambridge: Cambridge University Press, 2009.

----, "Southeast Asian Migrants", in Cape Town Between East and West: Social Identities in a Dutch Colonial Town, ed. by Nigel Worden, Cape Town: Jacana Media, 2012.

"Willem Adriaan van der Stel”, Wikipedia, https://en.wikipedia.org/w/ index.php?title=Willem_Adriaan_van_der_Stel\&oldid=951526567, accessed 31 Mar 2020. 